UNC-5138

\title{
STUDY OF URANIUM-PLUTONIUM MONOXIDES
}

Quarterly Progress Report

Period of July 1, 1965 through September 30, 1965

\section{Authors}

\section{United Nuclear}

R. L. Forbes, N. Fuhrman

The Carborundum Company

RETEEASED FOR ANNOUNCEMENT

J. Andersen, K. Taylor

IN MUCLSAR SCIENCE ABSTRACTS

October 30,1965

Approved: A. Strasser, Manager Plutonium Fuels Section

Joint U.S.-Euratom Research and Development Program

Work Performed on UNC Project 2321

Contract AT(30-1)-3305 with the

United States Atomic Energy Commission

Prime Contractor

UNITED NUCLEAR CORPORATION

Development Division

White Plains, New York

Subcontractor

THE CARBORUNDUM COMPANY

Niagara Falls, New York 


\begin{tabular}{ll}
\multicolumn{2}{c}{ Work Performed by } \\
United Nuclear Corporation & The Carborundum Company \\
C. Dwy & J. Andersen \\
R. Forbes & C. Boos \\
N. Fuhrman & T. Keaty \\
C. Johansen & K. Taylor \\
A. Koehl & \\
A. Magdics & \\
E. Stokhamer & \\
A. Strasser & \\
O. Sullivan &
\end{tabular}




\section{DISCLAIMER}

This report was prepared as an account of work sponsored by an agency of the United States Government. Neither the United States Government nor any agency Thereof, nor any of their employees, makes any warranty, express or implied, or assumes any legal liability or responsibility for the accuracy, completeness, or usefulness of any information, apparatus, product, or process disclosed, or represents that its use would not infringe privately owned rights. Reference herein to any specific commercial product, process, or service by trade name, trademark, manufacturer, or otherwise does not necessarily constitute or imply its endorsement, recommendation, or favoring by the United States Government or any agency thereof. The views and opinions of authors expressed herein do not necessarily state or reflect those of the United States Government or any agency thereof. 


\section{DISCLAIMER}

Portions of this document may be illegible in electronic image products. Images are produced from the best available original document. 


\begin{abstract}
Uranium-plutonium monoxide-type compositions stabilized with carbon, (UPu)(OC), were synthesized by carbon reduction of mixed $\mathrm{UO}_{2}$ and $\mathrm{PuO}_{2}$ in helium and vacuum. Materials containing as high as $85 \mathrm{w} / \mathrm{o}$ of a (UPu)(OC) composition were produced with oxygen atom fractions as high as 0.56 . Carbon-stabilized and nitrogen-stabilized uranium-plutonium monoxides, (UPu)(OCN), were synthesized by the uranium metal and carbon reduction routes in helium and vacuum. Essentially single-phase compositions were obtained having oxygen atom fractions as high as 0.36 .
\end{abstract}

Specimens containing (UPu)(OCN) compositions were subjected to water corrosion tests. A material containing $91 \mathrm{w} / \mathrm{o}$ of $\left(\mathrm{U}_{0.9} \mathrm{Pu}_{0.1}\right)\left(\mathrm{O}_{0.21} \mathrm{C}_{0.37} \mathrm{~N}_{0.42}\right)$ was intact after exposure to boiling water for $137 \mathrm{hr}$, but it disintegrated in $550^{\circ} \mathrm{F}$ water.

LEGAL NOTICE

This document was prepared under the sponsorship of the United States Atomic
Energy Commission pursuant to the Joint Research and Development Program
established by the Agreement for Cooperation signed November 8,1958 between
the Government of the United States of America and the European Atomic En-
ergy Community (Euratom). Nether the United States, the U. S. Atomic Energy
Commission, the European Atomic Energy Community, the Euratom Commis-
-ion, nor any person acting on behalf of either Commission
A. Makes any warranty or representation, express or implied, with respect to
the accuracy, completeness, or usefulness of the information contained in
this document, or that the use of any information, apparatus, method, or
process disclosed in this document may not infringe privately owned rights,
or

B. Assumes any liabilities with respect to the use of, or for damages resulting from the use of any information, apparatus, method or process disclosed in this document.

As used in the above, "person acting on behalf of either Commission" includes any employee or contractor of either Commision or employee of such chent that such employee or contractor or employee of such contractor prepares, handles, disseminates, or provides access to, any information pursuant to his employment or contract with either Commission or his employment wath such contractor. 


\section{FOREWORD}

The United States and the European Atomic Energy Community (Euratom), on May 29 and June 18, 1958, signed an agreement which provides a basis for cooperation in programs for the advancement of the peaceful applications of atomic energy. This agreement, in part, provides for the establishment of a Joint U.S.Euratom Research and Development Program which is aimed at reactors to be constructed under the Joint Program.

The work described in this report represents the Joint U.S.-Euratom effort which is in keeping with the spirit of cooperation in contributing to the common good by the sharing of scientific and technical information and minimizing the duplication of effort by the limited pool of technical talent available in Western Europe and the United States.

The study of uranium-plutonium monoxides is sponsored jointly by the USAEC and Euratom. The prime contractor is the United Nuclear Corporation, Development Division, and the subcontractor is The Carborundum Company. United Nuclear is conducting fabrication studies in vacuum and is performing property determinations. Carborundum is fabricating samples in helium.

This report summarizes progress for the period of July 1, 1965 through September 30,1965 . Previous progress was reported in: 
UNC-5096, Study of Uranium-Plutonium Monoxides, Progress Report, Period of February 1, 1964 through July 31, 1964 (Oct. 5, 1964).

UNC-5102, Study of Uranium-Plutonium Monoxides, Progress Report, Period of August 1, 1964 through October 31, 1964 (Dec. 28, 1964).

UNC-5117, Study of Uranium-Plutonium Monoxides, Progress Report, Period of November 1, 1964 through March 31, 1965 (Apr. 15, 1965).

UNC-5132, Study of Uranium-Plutonium Monoxides, Progress Report, Period of April 1, 1965 through June 30, 1965 (Sept. 15, 1965). 
TABLE OF CONTENTS

1. INTRODUCTION AND SUMMARY OF PRIOR

RESULTS . . . . . . . . . . . . . . . . . . . 1

2. SUMMARY OF PROGRESS THIS QUARTER . . . . . . . . . . . . 4

3. FABRICATION EXPERIMENTS . . . . . . . . . . . . 6

3.1 Introduction . . . . . . . . . . . . . . . . 6

3.2 Synthesis of $(\mathrm{UPu})(\mathrm{OC})$ Compositions . . . . . . . . . . 8

3.2.1 Intended $\left(\mathrm{U}_{0.9} \mathrm{Pu}_{0.1}\right)\left(\mathrm{O}_{0.6} \mathrm{C}_{0.4}\right)$ by

Carbon Reduction in Helium . . . . . . . . 8

3.2.2 Intended $\left(\mathrm{U}_{0.9} \mathrm{Pu}_{0.1}\right) \mathrm{O}$ by Carbon

Reduction in Helium . . . . . . . . 10

3.2.3 Intended $\left(\mathrm{U}_{0.9} \mathrm{Pu}_{0.1}\right) \mathrm{O}$ by Carbon

Reduction in Vacuum . . . . . . . . . . . 14

3.3 Synthesis of $(\mathrm{UPu})(\mathrm{OCN})$ Compositions . . . . . . . . . 16

3.3.1 Intended $\left(\mathrm{U}_{0.9} \mathrm{Pu}_{0.1}\right)\left(\mathrm{O}_{\mathrm{x}} \mathrm{C}_{0.2} \mathrm{~N}_{0.8-\mathrm{x}}\right)$ by

Uranium Metal Reduction in Helium . . . . . . . 16

3.3.2 Intended $(\mathrm{UPu})(\mathrm{OCN})$ by Uranium Metal

Reduction in Vacuum . . . . . . . . . 18

3.3.3 Intended (UPu)(OCN) by Carbon

Reduction in Vacuum . . . . . . . . 21

4. FUEL EVALUATION . . . . . . . . . . . . . . . . . 26

4.1 Introduction . . . . . . . . . . . . . . 26

4.2 Water Corrosion . . . . . . . . . . . . 26

4.2.1 Boiling Water Tests . . . . . . . . . 26

4.2.2 Autoclave Tests . . . . . . . . . . . . . 29

4.3 Thermal Diffusivity. . . . . . . . . . . . . 29

5. CONCLUSIONS ................... 31

6. WORK PLANNED FOR NEXT QUARTER . . . . . . . . . 33

7. REFERENCES .................... . . 34 


\section{TABLES}

1. Summary of Fabrication Experiments . . . . . . . . . . . . . 7

2. Synthesis of Intended $\left(\mathrm{U}_{0.9} \mathrm{Pu}_{0.1}\right)\left(\mathrm{O}_{0.6} \mathrm{C}_{0.4}\right)$ by Carbon Reduction of $\mathrm{UO}_{2}$ and $\mathrm{PuO}_{2}$ in Helium . . . . . . . . . . . 9

3. Synthesis of Intended $\left(\mathrm{U}_{0.9} \mathrm{Pu}_{0.1}\right) \mathrm{O}$ by Carbon Reduction of $\mathrm{UO}_{2}$ and $\mathrm{PuO}_{2}$ at $1750^{\circ} \mathrm{C}$ for $2 \mathrm{hr}$. . . . . . . . . . . . . . . 11

4. Synthesis of $\left(\mathrm{U}_{0.9} \mathrm{Pu}_{0.1}\right)\left(\mathrm{O}_{\mathrm{x}} \mathrm{C}_{0.2} \mathrm{~N}_{0.8-\mathrm{X}}\right)$ by Uranium Metal Reduction of $\mathrm{UO}_{2}$ and $\mathrm{PuO}_{2}$ with $\mathrm{UN}$ and UC in Helium

5. Synthesis of Intended $\left(\mathrm{U}_{0.9} \mathrm{Pu}_{0.1}\right)\left(\mathrm{O}_{\mathrm{X}} \mathrm{C}_{0.2} \mathrm{~N}_{0.8-\mathrm{X}}\right)$ by

Uranium Metal Reduction of $\mathrm{UO}_{2}$ and $\mathrm{PuO}_{2}$ with

$\mathrm{UC}$ and $\mathrm{UN}$ in Vacuum at $1650^{\circ} \mathrm{C}$ for $5 \mathrm{hr}$. . . . . . . . . . . . . . 18

6. Synthesis and Sintering of Intended $\left(\mathrm{U}_{0.9} \mathrm{Pu}_{0.1}\right)\left(\mathrm{O}_{0.5} \mathrm{C}_{\mathrm{y}} \mathrm{N}_{0.5-\mathrm{y}}\right)$ by Uranium Metal Reduction of $\mathrm{UO}_{2}$ and $\mathrm{PuO}_{2}$ with UC and UN in Vacuum . . . . . . . . . . . . . . . . . . . 20

7. Synthesis and Sintering of $\left(\mathrm{U}_{0.9} \mathrm{Pu}_{0.1}\right)\left(\mathrm{O}_{0.3} \mathrm{C}_{0.3} \mathrm{~N}_{0.4}\right)$ by

Uranium Metal Reduction of $\mathrm{UO}_{2}$ and $\mathrm{PuO}_{2}$ with UC and UN in Vacuum . . . . . . . . . . . . . . . . . . . 22

8. Synthesis and Sintering of Intended $\left(\mathrm{U}_{0.9} \mathrm{Pu}_{0.1}\right)\left(\mathrm{O}_{0.3} \mathrm{C}_{0.4} \mathrm{~N}_{0.3}\right)$ by Uranium Metal Reduction of $\mathrm{UO}_{2}$ and $\mathrm{PuO}_{2}$ with $\mathrm{UC}$ and UN in Vacuum . . . . . . . . . . . . . . . . . . . . 23

9. Synthesis of (UPu)(OCN) by Carbon Reduction of $\mathrm{UO}_{2}$ and $\mathrm{PuO}_{2}$ with $\mathrm{UN}$ in Vacuum at $1650^{\circ} \mathrm{C}$ for $5 \mathrm{hr}$. . . . . . . . . 25

10. Corrosion Data on $\left(\mathrm{U}_{0.9} \mathrm{Pu}_{0.1}\right)\left(\mathrm{O}_{0.21} \mathrm{C}_{0.37} \mathrm{~N}_{0.42}\right)$ after $137 \mathrm{hr}$ in Boiling Water . . . . . . . . . . . . . . . . . 27

\section{FIGURES}

1. Intended $\left(\mathrm{U}_{0.9} \mathrm{Pu}_{0.1}\right) \mathrm{O}$ Synthesized by Carbon Reduction in Helium at $1750^{\circ} \mathrm{C}$ for $2 \mathrm{hr}$ Showing Effect of Phenoformaldehyde Substitution for Carbon Powder . . . . . . . . . . . . . . . . . 13

2. Variation of Lattice Parameter of the $\mathrm{M}\left(\mathrm{O}_{1-\mathrm{X}} \mathrm{C}_{\mathrm{X}}\right)$ Phase with Oxygen Content . . . . . . . . . . . . . 15

3. Density Improvement on Sintering Intended $\left(\mathrm{U}_{0.9} \mathrm{Pu}_{0.1}\right)\left(\mathrm{O}_{0.3} \mathrm{C}_{0.4} \mathrm{~N}_{0.3}\right)$ Synthesis Product

4. Appearance of Specimen Containing $91 \mathrm{w} / \mathrm{o}$ $\left(\mathrm{U}_{0.9} \mathrm{Pu}_{0.1}\right)\left(\mathrm{O}_{0.21} \mathrm{C}_{0.37} \mathrm{~N}_{0.42}\right)$ before and after 137-hr Test in Boiling Water . . . . . . . . . . . . . 28

5. View of Autoclave Furnace, Piping, and Control Panel 


\section{INTRODUCTION AND SUMMARY OF PRIOR RESULTS}

The goal of this study is to find a monoxide-type fuel for water-cooled thermal reactors which has a heat generation capability better than, and a corrosion resistance equivalent to, $\mathrm{PuO}_{2}$ and $(\mathrm{UPu}) \mathrm{O}_{2}$.

The power generation limit of a given size fuel rod is directly proportional to the product of $\left[\mathrm{T}_{\text {fuel }}\right.$ center ( $\sim$ melting) $-\mathrm{T}_{\text {fuel surface }} \times$ fuel thermal conductivity. A higher heat generating (high thermal conductivity) fuel will permit fewer, larger diameter rods to be used. Fewer rods will lower fuel fabrication costs. Larger diameter rods will be mechanically more stable; sizes above 1/4-in. diameter are desirable for the long fuel rods of thermal reactors $(\sim 10 \mathrm{ft})$.

A high conductivity uranium-plutonium monoxide fuel would be of interest to the water-cooled converter power reactor systems. Homogeneous uranium-plutonium oxide mixtures can be used with a fissionable plutonium atom enrichment of about 5 to $8 \%$ to substitute for $\mathrm{U}^{235}$. This can reduce reliance on the availability of uranium isotope enrichment facilities. Although early core loarings would use $\mathrm{Pu}^{239}$, subsequent ones could use increasing amounts of $\mathrm{Pu}^{240}$ to increase the reactivity burnup limit of the reactor. Total plutonium concentrations in uranium would be up to $10 \%$.

The monoxides should have high thermal conductivity, based on the similarity of their crystal and electronic structure to known high thermal conductivity monocarbides and mononitrides. Uranium monoxide is not thermodynamically stable in 
massive form, but uranium-plutonium monoxide mixtures stabilized with carbon or nitrogen, or both, have been prepared in recent investigations. ${ }^{1-3}$

The specific objectives of this study are: (1) to fabricate uranium-plutonium monoxide-type compositions with or without stabilizers, such as carbon and nitrogen, and (2) to measure pertinent properties of promising materials, particularly water corrosion resistance and thermal diffusivity. Superior fuel compositions will be further characterized with respect to melting point, vapor pressure, and compatibility with clad materials.

Two synthesis routes are being studied: (1) reduction of the mixed dioxides $\left(\mathrm{PuO}_{2}\right.$ and $\mathrm{UO}_{2}$ ) by carbon, and (2) reduction by noncarbonaceous agents, such as uranium metal. The reactions are being carried out in helium and in vacuum. The fuels are evaluated by metallography, chemical analysis, X-ray diffraction, and density measurements.

The results of work prior to this quarterly period confirmed expectations that a pure monoxide, (UPu)O, could not be synthesized. However, essentially singlephase $(\mathrm{UPu})(\mathrm{OC})$ compositions could be prepared in helium and vacuum by reacting $\mathrm{UO}_{2}$ and $\mathrm{PuO}_{2}$ with carbon, or uranium metal with carbon stabilizer. For example, a $94 \%$ dense $(\mathrm{UPu})(\mathrm{OC})$ material resulted from reacting a mixture of $\mathrm{UO}_{2}, \mathrm{PuO}_{2}$, $\mathrm{UH}_{\mathrm{X}}$, and $\mathrm{UC}$ at $1650^{\circ} \mathrm{C}$ in helium. The composition was approximately $93 \mathrm{w} / \mathrm{o}$ $\mathrm{M}\left(\mathrm{O}_{0.34} \mathrm{C}_{0.66}\right)^{*}$ and $7 \mathrm{w} / \mathrm{o} \mathrm{MO}_{2}$. Further studies indicated that the maximum oxygen atom fraction of the $\mathrm{M}(\mathrm{OC})$ phase in the material produced in helium was 0.58 , while that in the material produced in vacuum was 0.89 . However, in both cases, the fraction of the $\mathrm{M}(\mathrm{OC})$ phase present was low.

Attempts to synthesize a high oxygen monoxide-type material stabilized with nitrogen, i.e., a $(\mathrm{UPu})(\mathrm{ON})$ compound, were unsuccessful in that a single-phase prod-

* $\mathrm{M}$ is an abbreviation for $\left(\mathrm{U}_{0.9} \mathrm{Pu}_{0.1}\right)$. The notation (UPu) is retained where a general class of materials is discussed. 
uct did not appear possible and the oxygen solubility in the monoxide phase was low.

The synthesis of $(\mathrm{UPu})(\mathrm{OCN})$ compounds was then undertaken in which nitrogen was substituted for some of the carbon in $(\mathrm{UPu})(\mathrm{OC})$ to improve water corrosion resistance. A material containing $91 \mathrm{w} / \mathrm{o} \mathrm{M}\left(\mathrm{O}_{0.21} \mathrm{C}_{0.37} \mathrm{~N}_{0.42}\right)$ was prepared reproducibly for corrosion testing by reacting a mixture of $\mathrm{UO}_{2}, \mathrm{PuO}_{2}, \mathrm{UC}, \mathrm{UH}_{\mathrm{X}}$, and $\mathrm{UN}$ at $1650^{\circ} \mathrm{C}$ in helium. This composition was virtually unaffected by a $73.5-\mathrm{hr}$ exposure to boiling water. However, essentially single-phase $\mathrm{M}\left(\mathrm{O}_{\mathbf{0 . 3 2}} \mathrm{C}_{\mathbf{0 . 6 8}}\right)$ disintegrated in a boiling water corrosion test.

Preliminary room temperature thermal diffusivity measurements on $\mathrm{M}(\mathrm{OC})$ materials indicated that compositions containing as little as 50\% monoxide-type phase have at least twice the thermal conductivity of $\mathrm{UO}_{2}$. 


\section{SUMMARY OF PROGRESS THIS QUARTER}

The synthesis of $(\mathrm{UPu})(\mathrm{OC})$ compositions (having intended oxygen atom fractions of 0.6 and 1.0 ) by carbon reduction in helium and vacuum was studied to produce single-phase materials containing high oxygen atom fractions. In the case of intended $\mathrm{M}\left(\mathrm{O}_{0.6} \mathrm{C}_{0.4}\right)$ synthesis in helium, it was found that the products after reaction at $1750^{\circ} \mathrm{C}$ contained a maximum monoxide-phase weight fraction and an oxygen atom fraction of $86 \mathrm{w} / \mathrm{o}$ and $0.38 \mathrm{a} / \mathrm{o}$, respectively.

The synthesis of intended MO was investigated to obtain the maximum oxygen atom fraction in the (UPu)(OC) phase. Extensive ball milling of the starting materials and the use of submicron $\mathrm{UO}_{2}$ having a particle size smaller than that employed previously did not improve upon earlier results. Although an oxygen atom fraction of 0.58 was obtained, the monoxide-phase weight fraction was only $58 \mathrm{w} / \mathrm{o}$. The use of phenolformaldehyde resin as a substitute for the usual carbon powder reducing agent produced a material containing $85 \mathrm{w} / \mathrm{o}$ of an $\mathrm{M}\left(\mathrm{O}_{0.56} \mathrm{C}_{0.44}\right)$ phase in a preliminary experiment.

The synthesis of materials containing (UPu)(OCN) compositions was studied because of their apparent superior boiling water corrosion resistance. The uranium metal reduction method was employed to study the effect of the variation of the intended oxygen atom fraction with a constant intended carbon fraction of 0.2 . In both helium and vacuum, monoxide-type phase weight fractions of greater than $95 \mathrm{w} / \mathrm{o}$ were obtained from reactions to synthesize intended $\mathrm{M}\left(\mathrm{O}_{0.2} \mathrm{C}_{0.2} \mathrm{~N}_{0.6}\right)$. 
Intended $\mathrm{M}\left(\mathrm{O}_{0.5} \mathrm{C}_{0.2} \mathrm{~N}_{0.3}\right)$ and $\mathrm{M}\left(\mathrm{O}_{0.5} \mathrm{C}_{0.4} \mathrm{~N}_{0.1}\right)$ were synthesized by uranium metal reduction and sintered in vacuum. The results indicated that the use of submicron $\mathrm{UO}_{2}$ in the reaction mixture did not increase the monoxide weight fraction of the product over the $79 \mathrm{w} / \mathrm{o}$ maximum previously obtained.

Test specimens containing (UPu)(OCN) weight fractions greater than $90 \mathrm{w} / \mathrm{o}$ were produced in a synthesis and sintering study of intended $\mathrm{M}\left(\mathrm{O}_{0.3} \mathrm{C}_{0.3} \mathrm{~N}_{0.4}\right)$ and $\mathrm{M}\left(\mathrm{O}_{0.3} \mathrm{C}_{0.4} \mathrm{~N}_{0.3}\right)$ by the uranium metal reduction in vacuum. The synthesis of these intended compositions by carbon reduction of the mixed dioxides and UN also yielded monoxide-phase weight fractions exceeding $90 \mathrm{w} / \mathrm{o}$.

Specimens containing $91 \mathrm{w} / \mathrm{o}$ of an $\mathrm{M}\left(\mathrm{O}_{0.21} \mathrm{C}_{0.37} \mathrm{~N}_{0.42}\right)$ composition did not change in weight or dimensions significantly after $137 \mathrm{hr}$ in boiling water. However, upon exposure to $550^{\circ} \mathrm{F}$ water in an autoclave this material disintegrated within $1 \mathrm{hr}$. 


\section{FABRICATION EXPERIMENTS}

\subsection{INTRODUCTION}

The fabrication effort during this reporting period included the following activities:

1. The preparation of single-phase (UPu)(OC) compositions having higher oxygen atom fractions than obtained previously was studied by carbon reduction in helium and vacuum.

2. Preparation of materials containing (UPu)(OCN) compositions was continued with the objective of maximizing the weight fraction of the monoxide phase and minimizing the carbon atom fraction. Synthesis was by the uranium metal reduction route in helium and vacuum. The effect of subsequent crushing and sintering on the density and composition of the reaction products was investigated.

The intended compositions and process variables investigated under items 1 and 2 above are summarized in Table 1.

The emphasis on maximizing the oxygen atom fraction and the nitrogen atom fraction of the monoxide phase was dictated by the results of the boiling water corrosion tests conducted in the previous quarter. 4 These showed that an oxygen atom fraction of 0.32 in essentially single-phase (UPu)(OC) was insufficient to prevent disintegration. However, good corrosion resistance was observed where 
TABLE 1 - SUMMARY OF FABRICATION EXPERIMENTS

Intended Composition (Atom Fraction Range)

\begin{tabular}{|c|c|c|c|c|c|}
\hline \multirow[b]{3}{*}{ Variables Investigated } & \multicolumn{5}{|c|}{ Intended Composition (Atom Fraction Range) } \\
\hline & \multicolumn{2}{|c|}{$(\mathrm{UPu})(\mathrm{OC})$} & \multicolumn{3}{|c|}{$(\mathrm{UPu})(\mathrm{OCN})$} \\
\hline & $\mathrm{O}_{0.6} \mathrm{C}_{0.4}$ & $\underline{\mathrm{O}_{1.0}}$ & $\mathrm{O}_{0.2 / 0.6} \mathrm{C}_{0.2} \mathrm{~N}_{0.6 / 0.2}$ & $\mathrm{O}_{0.5} \mathrm{C}_{0.2 / 0.4} \mathrm{~N}_{0.3 / 0.1}$ & $\mathrm{O}_{0.3 / 0.4} \mathrm{C}_{0.3 / 0.4} \mathrm{~N}_{0.3 / 0.4}$ \\
\hline \multicolumn{6}{|l|}{ Synthesis conditions } \\
\hline Method & \multicolumn{2}{|c|}{$\begin{array}{l}\text { Carbon reduction: } \\
9 \mathrm{UO}_{2}+\mathrm{PuO}_{2}+18 \mathrm{C} \rightarrow \\
10\left(\mathrm{U}_{0.9} \mathrm{Pu}_{0.1}\right)\left(\mathrm{O}_{0.6} \mathrm{C}_{0.4}\right)+14 \mathrm{CO} \uparrow\end{array}$} & \multicolumn{2}{|c|}{$\begin{array}{l}\text { Uranium metal reduction: } \\
5 \mathrm{UH}_{\mathrm{X}}+3 \mathrm{UO}_{2}+2 \mathrm{UN}+8 \mathrm{UC}+2 \mathrm{PuO}_{2} \rightarrow \\
20\left(\mathrm{U}_{0.9} \mathrm{Pu}_{0.1}\right)\left(\mathrm{O}_{0.5} \mathrm{C}_{0.4} \mathrm{~N}_{0.1}\right)+5 \mathrm{x} / 2 \mathrm{H}_{2} \uparrow\end{array}$} & $\begin{array}{l}\text { Uranium metal reduction } \\
\text { Carbon reduction }\end{array}$ \\
\hline Atmosphere & Helium & Helium & Helium & Vacuum & Vacuum \\
\hline & - & Vacuum & Vacuum & - & - \\
\hline Time, ${ }^{\circ} \mathrm{C}$ (hold time, & 1750 & $1750(2)$ & $1650(5)$ & $1650(5)$ & 1550 to $1750(5)$ \\
\hline hr) & $(1 / 2$ to 3$)$ & $1650(5)$ & - & - & $1650(5)$ \\
\hline \multicolumn{6}{|l|}{ Blend unifor mity } \\
\hline Ball milling time, hr & 72 & 24 vs 72 & - & - & - \\
\hline $\mathrm{UO}_{2}$ particle size, $\mu$ & 3 & 0.5 vs 3 & 0.5 & 0.5 & 0.5 \\
\hline $\begin{array}{l}\text { Temp, }{ }^{\circ} \mathrm{C} \text { (hold time, } \\
\text { hr) }\end{array}$ & - & - & - & $1650(3)$ & $1650(3)$ \\
\hline \multicolumn{6}{|l|}{ Other variables } \\
\hline $\begin{array}{l}\text { Form of reducing } \\
\text { agent }\end{array}$ & - & $\begin{array}{l}\text { Carbon powder vs } \\
\text { phenolformaldehyde }\end{array}$ & - & - & - \\
\hline Synthesized for m & - & Granules vs pellets & 一 & 一 & - \\
\hline
\end{tabular}


the sum of the oxygen and nitrogen atom fractions was 0.63 in a (UPu)(OCN) composition.

As in earlier work, a uranium-plutonium ratio of $9: 1$ was used to represent the maximum enrichment representative of plutonium-fueled thermal reactors.

\subsection{SYNTHESIS OF (UPu)(OC) COMPOSITIONS}

\subsubsection{Intended $\left(\mathrm{U}_{0.9} \mathrm{Pu}_{0.1}\right)\left(\mathrm{O}_{0.6} \mathrm{C}_{0.4}\right)$ by Carbon Reduction in Helium}

Synthesis experiments to produce intended $\mathrm{M}\left(\mathrm{O}_{0.6} \mathrm{C}_{0.4}\right)$ by carbon reduction of the mixed dioxides in helium were conducted with the aim of obtaining compositions having substantially higher oxygen atom fractions than 0.32 , which was demonstrated to be too low for water corrosion resistance. Previous studies with this intended composition involved a synthesis temperature of $1650^{\circ} \mathrm{C}$ which led to oxygen atom fractions no higher than $0.32 .{ }^{4}$ During this reporting period, the effect on composition of raising the synthesis temperature to $1750^{\circ} \mathrm{C}$ was investigated. In addition, to promote a more complete reaction, the starting materials were blended by ball milling for $72 \mathrm{hr}$ instead of the usual $24 \mathrm{hr}$.

The synthesis conditions and the results of product characterization are shown in Table 2. The monoxide-phase weight fractions, * ranging from 82 to $86 \mathrm{w} / \mathrm{o}$, and the oxygen atom fractions, ranging from 0.36 to 0.38 , are not significantly better than those obtained from earlier carbon reduction of intended (UPu)(OC) compositions. Furthermore, these weight fractions are somewhat less than the

\footnotetext{
*The weight fraction of the monoxide phase is calculated from volume fraction data obtained by a point count technique, and from phase densities obtained by the $\mathrm{X}$-ray diffraction method. The carbon atom fraction of the monoxide-type phase is calculated by assuming all the carbon in the product is in that phase. The oxygen atom fraction of the monoxide-type phase is then determined by difference.
} 
TABLE 2 - SYNTHESIS OF INTENDED $\left(\mathrm{U}_{0.9} \mathrm{Pu}_{0.1}\right)\left(\mathrm{O}_{0.6} \mathrm{C}_{0.4}\right)$ BY CARBON REDUCTION OF UO AND PuO $_{2}$ IN HELIUM

\begin{tabular}{|c|c|c|c|c|c|c|c|}
\hline \multirow{2}{*}{$\begin{array}{l}\text { Exp. } \\
\text { No. }\end{array}$} & \multirow{2}{*}{$\begin{array}{c}\text { Temp, }{ }^{\circ} \mathrm{C} \\
\text { (Hold Time, hr) }\end{array}$} & \multirow[b]{2}{*}{ Material Form } & \multirow{2}{*}{$\begin{array}{c}\text { Carbon Content } \\
\text { of Reacted } \\
\text { Product, } \% \\
\end{array}$} & \multirow{2}{*}{$\begin{array}{c}\text { Amount of } \\
\mathbf{M}^{*}(\mathrm{OC}) \text { Phase } \\
\text { Excluding } \\
\text { Pores, w/o }\end{array}$} & \multirow{2}{*}{$\begin{array}{c}\text { Corrected } \\
\mathrm{M}(\mathrm{OC}) \text { Composition } \dagger\end{array}$} & \multicolumn{2}{|c|}{$\mathrm{X}$-Ray Diffraction Analysis } \\
\hline & & & & & & Phase Intensity & Lattice Parameter \\
\hline 1 & $1750\left(1 \frac{1}{2}\right)$ & $\begin{array}{l}\text { Wafer, }<1 / 16 \text {-in. thick } \\
\times 1 / 4 \text {-in. diameter }\end{array}$ & 2.48 & 82 & $\mathrm{M}\left(\mathrm{O}_{0.37} \mathrm{C}_{0.63}\right)$ & $\begin{array}{l}\text { Strong } \mathrm{M}(\mathrm{OC}) \\
\text { Strong } \mathrm{MO}_{2-\mathrm{x}}\end{array}$ & $\begin{array}{l}4.9573 \pm 0.0009 \\
5.4770 \pm 0.0005\end{array}$ \\
\hline 2 & $1750(3)$ & $\begin{array}{l}\text { Wafer, }<1 / 16 \text {-in. thick } \\
\times 1 / 4-\text { in. diameter }\end{array}$ & 2.49 & 84 & $\mathrm{M}\left(\mathrm{O}_{0.38} \mathrm{C}_{0.62}\right)$ & $\begin{array}{l}\text { Strong } \mathrm{M}(\mathrm{OC}) \\
\text { Strong } \mathrm{MO}_{2-\mathrm{x}}\end{array}$ & $\begin{array}{l}4.9567 \pm 0.0005 \\
5.4781 \pm 0.0011\end{array}$ \\
\hline 3 & $1750(2)$ & $\begin{array}{l}\text { Pellet, 1/4-in. thick } \\
\times 1 / 4 \text {-in. diameter }\end{array}$ & 2.52 & 83 & $\mathrm{M}\left(\mathrm{O}_{0.38} \mathrm{C}_{0.64}\right)$ & $\begin{array}{l}\text { Strong } \mathbf{M}(\mathrm{OC}) \\
\text { Strong } \mathrm{MO}_{2-\mathbf{x}}\end{array}$ & ${ }^{4.9585 \pm 0.0009}$ \\
\hline 4 & $1750(2)+$ & $\begin{array}{r}\text { Pellet, } 1 / 4 \text {-in. thick } \\
\times 1 / 4 \text {-in. diameter }\end{array}$ & 2.57 & 86 & $M\left(\mathrm{O}_{0.38} \mathrm{C}_{0.62}\right)$ & $\begin{array}{l}\text { Strong } \mathbf{M}(\mathrm{OC}) \\
\text { Strong } \mathrm{MO}_{2-\mathrm{x}}\end{array}$ & $\begin{array}{c}4.9565 \pm 0.0004 \\
-\end{array}$ \\
\hline
\end{tabular}


$92 \mathrm{w} / \mathrm{o}$ minimum achieved previously with intended $\mathrm{M}\left(\mathrm{O}_{0.5} \mathrm{C}_{0.5}\right)^{4}{ }^{4}$ On the basis of these results, no further synthesis of intended $\mathrm{M}\left(\mathrm{O}_{0.6} \mathrm{C}_{0.4}\right)$ is planned.

\subsubsection{Intended $\left(\mathrm{U}_{0.9} \mathrm{Pu}_{0.1}\right) \mathrm{O}$ by Carbon Reduction in Helium}

To produce materials with higher oxygen atom fractions in the (UPu)(OC) phase, the synthesis of intended MO by carbon reduction in helium was also studied. Previous work on this composition produced monoxide-phase weight fractions as high as $59 \mathrm{w} / \mathrm{o}$ and oxygen atom fractions as high as $0.58 .^{5}$ The effort this quarter to improve upon this result involved investigations of the following: (1) the effect of ball milling $72 \mathrm{hr}$ instead of the usual $24 \mathrm{hr}$, (2) the effect of using $\mathrm{UO}_{2}$ of 0.5 -micron particle size rather than the usual 3-micron starting material, and (3) the effect of firing a granulated reaction mixture instead of conventional cold pressed pellets. The first two process variations were designed to produce blends more homogeneous than those reacted in previous syntheses. In the case of the third process change, it was anticipated that the $\mathrm{CO}$ evolved in the reaction would escape more readily from the granules than from larger, more dense, cold pressed pellets, and therefore would promote a more complete reaction.

The experimental procedure consisted of ball milling one reaction mixture of $\mathrm{UO}_{2}, \mathrm{PuO}_{2}$, and $\mathrm{C}$ for $72 \mathrm{hr}$ and another mixture for only $24 \mathrm{hr}$. Carbowax 6000 ( $0.4 \mathrm{w} / \mathrm{o}$ of total solids) dissolved in benzene was added to the blends and approximately $1 / 8$-in. diameter granules were formed by stirring the resulting paste. Ten grams of each batch of granules were heated in a tantalum-lined graphite crucible for $2 \mathrm{hr}$ at $1750^{\circ} \mathrm{C}$ in flowing helium. The results in Table 3 under Experiments 1 and 2 show no substantial improvement in monoxide-phase weight fraction and oxygen atom fraction over that previously found. Furthermore, prolonged ball milling did not appear to have any beneficial effect.

To determine the effect of $\mathrm{UO}_{2}$ particle size variation, pellets were cold pressed at 200 psi from $24-\mathrm{hr}$ ball milled reaction mixtures. The data in Table 3 for the 
TABLE 3 - SYNTHESIS OF INTENDED $\left(\mathrm{U}_{0.9} \mathrm{Pu}_{0.1}\right)$ O BY CARBON REDUCTION OF $\mathrm{UO}_{2}$ AND $\mathrm{PuO}_{2}$ AT $1750^{\circ} \mathrm{C}$ FOR $2 \mathrm{HR}$

\begin{tabular}{|c|c|c|c|c|c|c|}
\hline \multirow{2}{*}{$\begin{array}{l}\text { Exp. } \\
\text { No. }\end{array}$} & \multirow{2}{*}{$\begin{array}{c}\text { Ball } \\
\text { Milling } \\
\text { Time, hr }\end{array}$} & \multirow[b]{2}{*}{ Material Form } & \multirow{2}{*}{$\begin{array}{c}\text { Amount of } \\
M^{*}(O C) \text { Phase } \\
\text { Excluding } \\
\text { Pores, w/o } \\
\end{array}$} & \multirow{2}{*}{$\begin{array}{c}\text { Corrected } \\
\mathbf{M}(\mathrm{OC}) \\
\text { Composition } \dagger \\
\end{array}$} & \multicolumn{2}{|c|}{$\begin{array}{c}\text { X-Ray Diffraction Analysis, } \\
\text { Phases Present, and Lattice } \\
\text { Parameter, } \AA \\
\end{array}$} \\
\hline & & & & & $\mathrm{M}(\mathrm{OC})$ & $\mathrm{MO}_{2-\mathrm{x}}$ \\
\hline 1 & 72 & Granulated & 58 & $\mathrm{M}\left(\mathrm{O}_{0.58} \mathrm{C}_{0.42}\right)$ & $4.9536 \pm 0.0012$ & $5.4795 \pm 0.0009$ \\
\hline 2 & 24 & Granulated & 58 & $\mathrm{M}\left(\mathrm{O}_{0.58} \mathrm{C}_{0.42}\right)$ & $4.9530 \pm 0.0011$ & $5.4801 \pm 0.0011$ \\
\hline 3 & 24 & Pellet & 55 & $M\left(O_{0.55} C_{0.45}\right)$ & $4.9527 \pm 0.0009$ & $5.4818 \pm 0.0007$ \\
\hline $4 \mp$ & 24 & Pellet & 55 & $\mathrm{M}\left(\mathrm{O}_{0.58} \mathrm{C}_{0.42}\right)$ & $4.9530 \pm 0.0015$ & $5.4807 \pm 0.0018$ \\
\hline
\end{tabular}


two $\mathrm{UO}_{2}$ starting materials (Experiments 3 and 4) indicate that the products of synthesis at $1750^{\circ} \mathrm{C}$ were similar.

Metallographic examination of the intended MO synthesis products revealed segregation of the $\mathrm{M}(\mathrm{OC})$ and $\mathrm{MO}_{2-\mathrm{x}}$ phases (see Fig. 1a). Therefore, an attempt was made to improve the reaction blend uniformity by substituting liquid phenolformaldehyde resin for the powdered carbon normally used. It was anticipated that the resin would cover the $\mathrm{MO}_{2}$ particles uniformly and that subsequent removal of gaseous products during initial heating would later provide the necessary continuous network of pores for adequate $\mathrm{CO}$ removal. The amount of carbon residue produced by heating this resin varies from about 30 to $50 \%$, depending upon heating conditions, i.e., rate of heating, other materials present, atmosphere, etc. Assuming that the carbon residue would be $35 \%$ of the original resin weight, a batch of mixed dioxides with liquid phenolformaldehyde was formulated to produce intended MO.

Compacts were pressed and cured at $150^{\circ} \mathrm{C}$ and heated to $1750^{\circ} \mathrm{C}$ for 70 minutes. The synthesis product contained $85 \mathrm{w} / \mathrm{o}$ of a calculated $\mathrm{M}\left(\mathrm{O}_{\mathbf{0 . 3 6}} \mathrm{C}_{\mathbf{0 . 4 4}}\right)$ phase. $\mathrm{X}$-ray diff raction analysis indicated the usual $\mathrm{MO}_{2-\mathrm{x}}$ phase $\left(\mathrm{a}_{0}=5.4832 \pm 0.0020 \AA\right)$, and a strong $\mathrm{M}(\mathrm{OC})$ type $\left(\mathrm{a}_{0}=4.9523 \pm 0.0005 \AA\right)$.

A carbon material balance on the reaction mixture and the product obtained indicated that the original mixture contained more carbon than the stoichiometric amount required for intended MO synthesis. Nevertheless, the product homogeneity was improved (see Fig. 1b) and although the oxygen atom fraction has not been significantly increased, this technique promises to yield higher weight fractions of the high oxygen $\mathrm{M}(\mathrm{OC})$ than previously obtained. Further development is required, however, to optimize the process. 


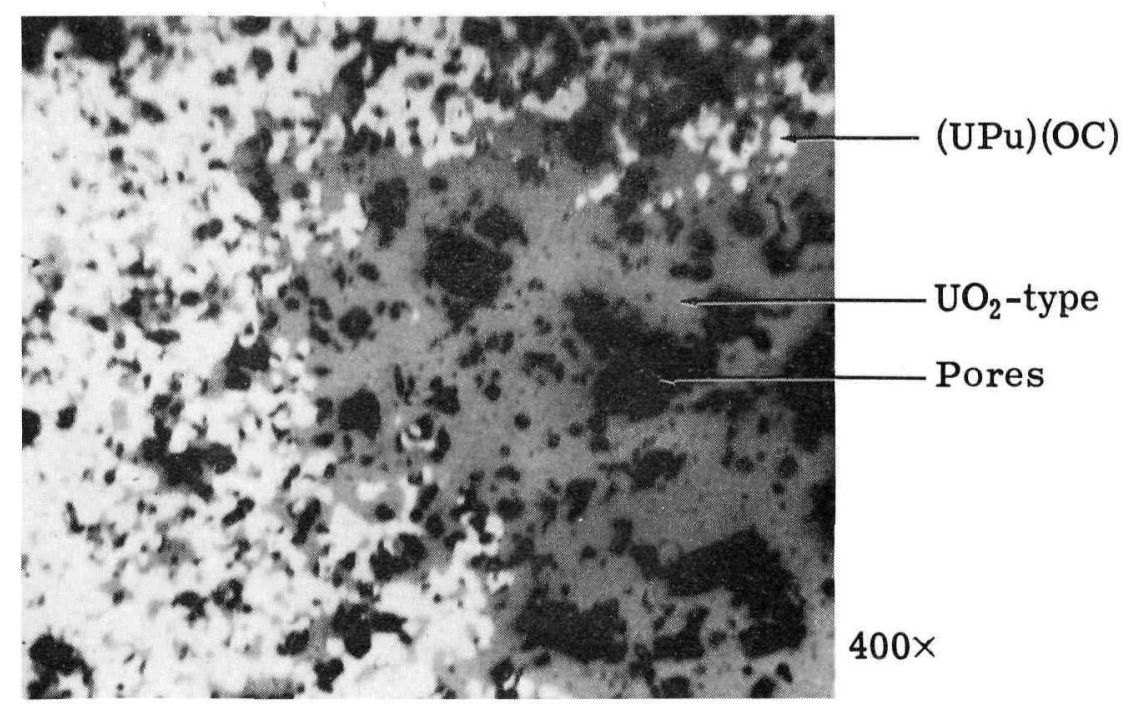

a. Product of standard carbon reduction showing nonuniform distribution of phases

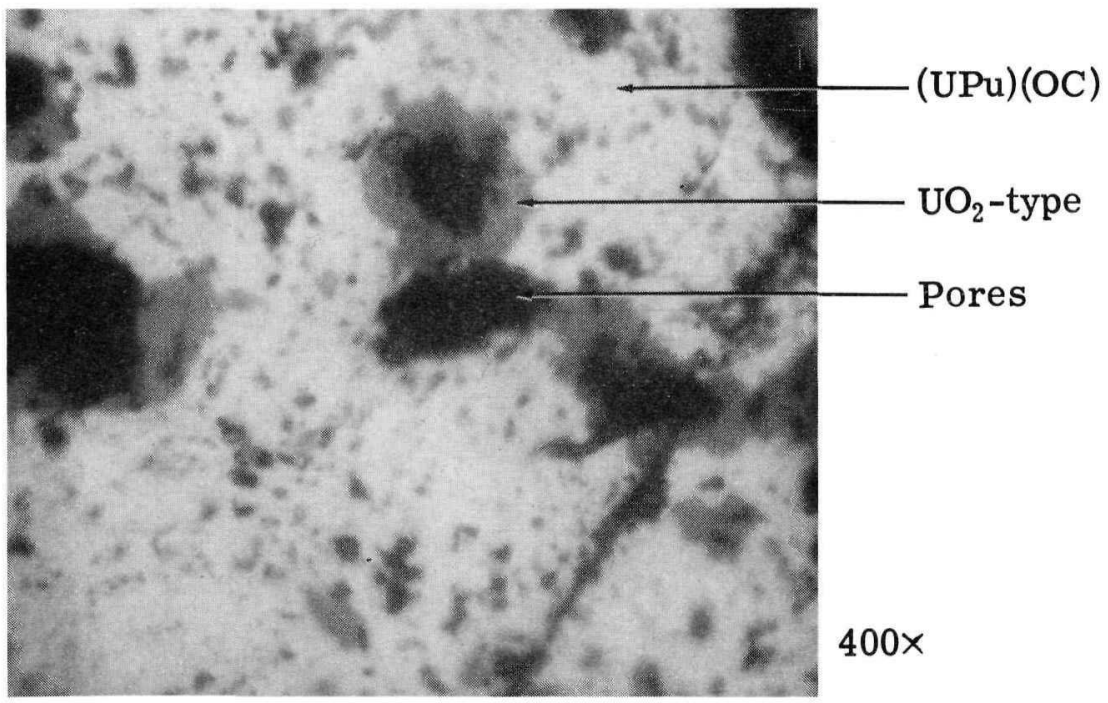

b. Improved distribution after substituting phenolformaldehyde for carbon powder

Fig. 1 - Intended $\left(\mathrm{U}_{0.9} \mathrm{Pu}_{0.1}\right) \mathrm{O}$ Synthesized by Carbon Reduction in Helium at $1750^{\circ} \mathrm{C}$ for $2 \mathrm{hr}$ Showing Effect of Phenolformaldehyde Substitution for Carbon Powder 


\subsubsection{Intended $\left(\mathrm{U}_{0.9} \mathrm{Pu}_{0.1}\right) \mathrm{O}$ by Carbon Reduction in Vacuum}

In previous work, ${ }^{5}$ the most promising product of an intended MO synthesis by carbon reduction in vacuum contained $60 \mathrm{w} / \mathrm{o}$ of an $\mathrm{M}\left(\mathrm{O}_{0.60} \mathrm{C}_{0.40}\right)$ phase. During this quarter, the effect of using the 0.5 -micron particle size $\mathrm{UO}_{2}$ was investigated. It was expected that this relatively fine starting material would blend more efficiently with the $\mathrm{PuO}_{2}$ and $\mathrm{C}$, react more completely, and, the refore, produce more nearly single-phase (UPu)(OC) with a higher oxygen atom fraction.

The starting materials were blended in a 3-ml Spex* mill for $1 \mathrm{hr}$ and were compacted without binder at forming pressures of 15,000,30,000, and 60,000 psi. Compacts representing the three pressing conditions were heated at $1650^{\circ} \mathrm{C}$ for $5 \mathrm{hr}$. A preliminary evaluation indicated that the compacts pressed at $30,000 \mathrm{psi}$ produced the maximum monoxide weight fraction. The reproducibility of the process was checked by a second run. A complete metallographic examination of the two synthesis products showed that they were similar; but, in both cases, large cracks were found around which an $\mathrm{MO}_{2-\mathrm{x}}$ phase was concentrated. $\mathrm{Be}-$ cause monoxide-phase weight fraction and oxygen atom fraction data obtained from such inhomogeneous structures by the usual point count technique are believed unreliable, the synthesis products were analyzed by $\mathrm{X}$-ray diffraction. Although quantitative weight fraction data cannot be obtained from this analysis, the oxygen atom fraction of the $\mathrm{M}(\mathrm{OC})$ phase can be estimated fairly accurately by comparison of the indicated lattice parameter with the lattice parameteroxygen atom fraction correlation developed previously for $\mathrm{M}(\mathrm{OC})$ compositions (see Fig. 2). The lattice parameters of $4.9523 \pm 0.0006 \AA$ and $4.9528 \pm 0.0007 \AA$ for the $\mathrm{M}(\mathrm{OC})$ type phases of the two synthesis products correspond to an oxygen atom fraction of approximately 0.6 .

This is not significantly different from the best values obtained with the 3-micron $\mathrm{UO}_{2}$ starting material so that there is no obvious advantage in using the submicron

\footnotetext{
${ }^{*}$ A commercial oscillating shaker made by Spex Industries.
} 


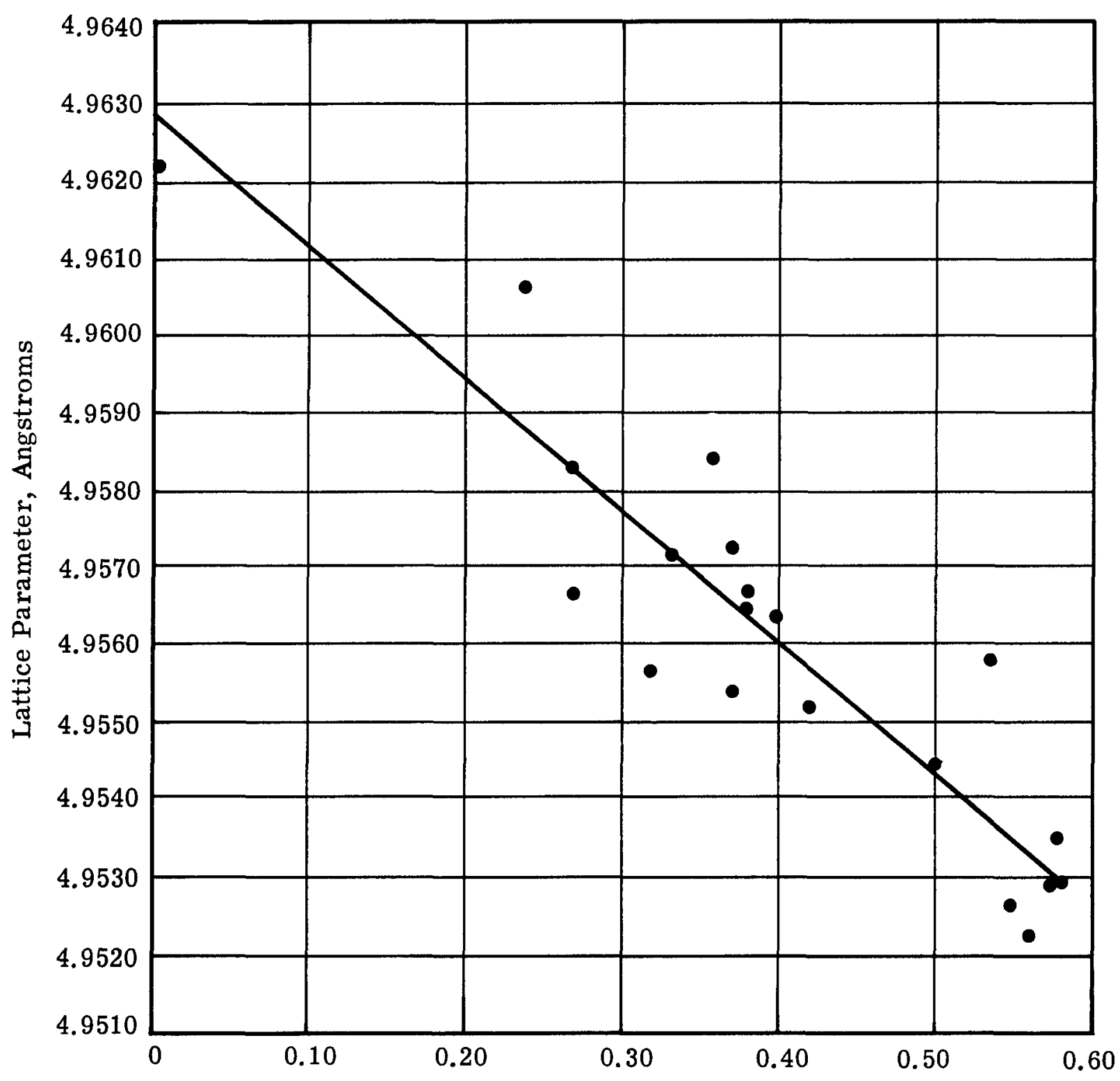

Atoms of Oxygen in Calculated $\mathrm{M}\left(\mathrm{O}_{1-\mathrm{X}} \mathrm{C}_{\mathrm{X}}\right)$ Solid Solution

Fig. 2 - Variation of Lattice Parameter of the $M\left(O_{1-x} C_{x}\right)$ Phase with Oxygen Content. Carbon Reduction of $\mathrm{UO}_{2}$ and $\mathrm{PuO}_{2}$ at $1750^{\circ} \mathrm{C}$. 
$\mathrm{UO}_{2}$. The oxygen atom fraction is in good agreement with those obtained from intended MO synthesis by the standard carbon reduction in helium.

\subsection{SYNTHESIS OF (UPu)(OCN) COMPOSITIONS}

\subsubsection{Intended $\left(\mathrm{U}_{0.9} \mathrm{Pu}_{0.1}\right)\left(\mathrm{O}_{\mathrm{x}} \mathrm{C}_{0.2} \mathrm{~N}_{0.8-\mathrm{x}}\right)$ by Uranium Metal Reduction in Helium}

The objective of synthesizing $\mathrm{M}(\mathrm{OCN})$ compositions by uranium metal reduction was to make an essentially single-phase product with superior stability in high temperature water. Previous boiling water corrosion tests indicated that monoxide-type materials with minimal carbon content would have the best corrosion resistance. Therefore, an effort in this reporting period involved intended compositions with the carbon atom fraction fixed at 0.2 . The intended oxygen and nitrogen atom fractions were varied from 0.2 to 0.6 , as shown in Table 3 .

The reaction mixtures were blended for 30 minutes in a 25-ml Spex mixer, pressed into $1 / 4$-in. diameter pellets, and heated for $5 \mathrm{hr}$ at $1650^{\circ} \mathrm{C}$ in a tantalumlined graphite crucible with a helium flow of $6 \mathrm{ft}^{3} / \mathrm{hr}$. The results in Table 4 indicate that the product metal content decreases and the monoxide weight fraction increases with decreasing intended oxygen. On the basis of these, data the product of the intended $\mathrm{M}\left(\mathrm{O}_{0.2} \mathrm{C}_{0.2} \mathrm{~N}_{0.6}\right)$ synthesis was deemed sufficiently promising for water corrosion testing. The last experiment in Table 4 presents the characterization data on a sample representing 12 specimens fabricated for such tests. A comparison with the data on the original synthesis product demonstrates the good reproducibility of the fabrication process.

\subsubsection{Intended (UPu)(OCN) by Uranium Metal Reduction in Vacuum}

\section{A. Intended $\mathrm{M}\left(\mathrm{O}_{\mathrm{x}} \mathrm{C}_{0.2} \mathrm{~N}_{0.8-\mathrm{x}}\right)$ Compositions}

In view of the favorable helium atmosphere results described in Section 3.3.1, three compositions with intended carbon atom fractions of 0.2 were synthesized 
TABLE $4-$ SYNTHESIS OF $\left(\mathrm{U}_{0.9} \mathrm{Pu}_{0.1}\right)\left(\mathrm{O}_{\mathrm{X}} \mathrm{C}_{0.2} \mathrm{~N}_{0.8-\mathrm{X}}\right)$ BY URANIUM METAL REDUCTION OF $\mathrm{UO}_{2}$ AND $\mathrm{PuO}_{2}$ WITH UN AND UC IN HELIUM

Metallographic Results, Phases Present, and

\begin{tabular}{|c|c|c|c|c|c|}
\hline \multirow{2}{*}{$\begin{array}{c}\text { Intended } \\
\text { Composition* } \\
\end{array}$} & \multicolumn{3}{|c|}{$\begin{array}{l}\text { Phases Present, and } \\
\text { Amount, w/o }\end{array}$} & \multirow{2}{*}{$\begin{array}{c}\text { Corrected } \\
\text { M(OCN) } \\
\text { Composition } \dagger \\
\end{array}$} & \multirow{2}{*}{$\begin{array}{c}\mathrm{M}(\mathrm{OCN}) \\
\text { Lattice } \\
\text { Parameter, } \AA \\
\end{array}$} \\
\hline & $\mathrm{I}(\mathrm{OCN})$ & $\mathrm{MO}_{2-\mathrm{x}}$ & Metal & & \\
\hline$\left(\mathrm{O}_{0}\right.$ & 58 & 26 & 16 & $\mathrm{M}(\mathrm{O}$ & 4.927 \\
\hline $\mathrm{I}\left(\mathrm{O}_{0}\right.$ & 73 & 16 & 1 & $\mathrm{M}\left(\mathrm{O}_{0}\right.$ & 4.922 \\
\hline$\Lambda\left(\mathrm{O}_{0}\right.$ & 76 & 13 & 11 & $\mathrm{M}\left(\mathrm{O}_{0.16} \mathrm{C}_{0.31} \mathrm{~N}_{0.53}\right)$ & 4.9173 \\
\hline $\mathrm{M}\left(\mathrm{O}_{0}\right.$ & 88 & 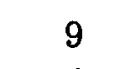 & 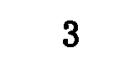 & $\mathrm{M}(\mathrm{O}$ & \\
\hline $\mathrm{M}\left(\mathrm{O}_{0.2} \mathrm{C}\right.$ & 96 & 4 & - & $M\left(O_{0.14} C_{0.24} N_{0.62}\right)$ & $4.9126 \pm 0.000$ \\
\hline $\mathrm{M}\left(\mathrm{O}_{0.2} \mathrm{C}_{0.2} \mathrm{~N}_{0.6}\right) \ddagger$ & 96 & 4 & - & $\mathrm{M}\left(\mathrm{O}_{0.10} \mathrm{C}_{0.28} \mathrm{~N}_{0.62}\right)$ & \\
\hline
\end{tabular}

$* \mathrm{M}=\left(\mathrm{U}_{0.9} \mathrm{Pu}_{0.1}\right)$.

†Composition was calculated from point count, carbon content, and X-ray density. Nitr ogen content assumed to be same as intended.

\$Pellets for water corrosion tests.

by uranium metal reduction in vacuum: $\mathrm{M}\left(\mathrm{O}_{0.2} \mathrm{C}_{0.2} \mathrm{~N}_{0.6}\right), \mathrm{M}\left(\mathrm{O}_{0.3} \mathrm{C}_{0.2} \mathrm{~N}_{0.5}\right)$, and $M\left(\mathrm{O}_{0.4} \mathrm{C}_{0.2} \mathrm{~N}_{0.4}\right)$. Compacts of the blended starting materials were prepared in the usual manner and heated at $1650^{\circ} \mathrm{C}$ for $5 \mathrm{hr}$. The characterization data on these products are summarized in Table 5. As in the case of the helium atmosphere work, an essentially single-phase material was produced from the intended $\mathrm{M}\left(\mathrm{O}_{0.2} \mathrm{C}_{0.2} \mathrm{~N}_{0.6}\right)$ synthesis.

\section{B. Intended $\mathrm{M}\left(\mathrm{O}_{0,5} \mathrm{C}_{\mathrm{y}} \mathrm{N}_{0,5-\mathrm{y}}\right)$ Compositions}

At the beginning of the reporting period, several syntheses by uranium metal reduction in vacuum were conducted to reproduce two promising $\mathrm{M}(\mathrm{OCN})$ materials resulting from the previous quarter's survey in which the intended oxygen atom fraction ranged from 0.5 to $0.8 .^{4}$ These contained the highest monoxide-phase weight fractions found: $77 \mathrm{w} / \mathrm{o}$ of $\mathrm{M}\left(\mathrm{O}_{0.36} \mathrm{C}_{0.45} \mathrm{~N}_{0.19}\right)$ synthesized from an intended $\mathrm{M}\left(\mathrm{O}_{0.5} \mathrm{C}_{0.4} \mathrm{~N}_{0.1}\right)$, and $79 \mathrm{w} / \mathrm{o}$ of $\mathrm{M}\left(\mathrm{O}_{0.20} \mathrm{C}_{0.27} \mathrm{~N}_{0.53}\right)$ synthesized from an intended $\mathrm{M}\left(\mathrm{O}_{0.5} \mathrm{C}_{0.2} \mathrm{~N}_{0.3}\right)$, respectively. 
TABLE 5 - SYNTHESIS OF INTENDED $\left(\mathrm{U}_{0.9} \mathrm{Pu}_{0.1}\right)\left(\mathrm{O}_{\mathrm{x}} \mathrm{C}_{0.2} \mathrm{~N}_{0.8-\mathrm{x}}\right)$ BY URANIUM METAL REDUCTION OF UO AND PuO $_{2}$ WITH UC AND UN IN VACUUM AT $1650^{\circ} \mathrm{C}$ FOR 5 HR

\begin{tabular}{|c|c|c|c|c|c|c|c|c|c|c|c|c|}
\hline \multirow[b]{2}{*}{$\begin{array}{l}\text { Exp. } \\
\text { No. }\end{array}$} & \multirow[b]{2}{*}{$\begin{array}{c}\text { Intended } \\
\text { Composition* }\end{array}$} & \multicolumn{3}{|c|}{ Carbon Content, w/o } & \multicolumn{3}{|c|}{ Nitrogen Content, w/o } & \multicolumn{3}{|c|}{$\begin{array}{c}\text { Metallographic Results, } \\
\text { Phases Present, and } \\
\text { Amount, w/o } \\
\end{array}$} & \multirow{2}{*}{$\begin{array}{c}\text { Corrected } \\
\text { M(OCN) } \\
\text { Composition } \dagger \\
\end{array}$} & \multirow[b]{2}{*}{$\begin{array}{l}\text { Density, } \\
\mathrm{g} / \mathrm{cm}^{3}\end{array}$} \\
\hline & & $\begin{array}{c}\text { Total } \\
\text { Intended }\end{array}$ & $\begin{array}{r}\text { Total } \\
\text { Actual } \\
\end{array}$ & $\begin{array}{l}\text { Contained } \\
\text { in } M(O C N)\end{array}$ & $\begin{array}{c}\text { Total } \\
\text { Intended }\end{array}$ & $\begin{array}{c}\text { Total } \\
\text { Actual }\end{array}$ & $\begin{array}{l}\text { Contained } \\
\text { in } \mathrm{M}(\mathrm{OCN})\end{array}$ & $\frac{\mathrm{An}}{\mathrm{M}(\mathrm{OCN})}$ & $\frac{\mathrm{MO}_{2-\mathrm{x}}}{\mathrm{M}}$ & Metal & & \\
\hline 83 & $\mathrm{M}\left(\mathrm{O}_{0.2} \mathrm{C}_{0.2} \mathrm{~N}_{0.6}\right)$ & 0.95 & 0.96 & 0.99 & 3.33 & 4.05 & 4.18 & 97 & 3 & - & $\mathrm{M}\left(\mathrm{O}_{0.04} \mathrm{C}_{0.21} \mathrm{~N}_{0.75}\right)$ & 11.1 \\
\hline 84 & $\mathrm{M}\left(\mathrm{O}_{0.3} \mathrm{C}_{0.2} \mathrm{~N}_{0.5}\right)$ & 0.95 & 0.93 & 0.98 & 2.77 & 3.50 & 4.08 & 86 & 9 & 5 & $\mathrm{M}\left(\mathrm{O}_{0.05} \mathrm{C}_{0.22} \mathrm{~N}_{0.73}\right)$ & 10.6 \\
\hline 85 & $\mathrm{M}\left(\mathrm{O}_{0.4} \mathrm{C}_{0.2} \mathrm{~N}_{0.4}\right)$ & 0.95 & 0.97 & 1.19 & 2.22 & 2.86 & 3.51 & 81 & 19 & - & $\mathrm{M}\left(\mathrm{O}_{0,13} \mathrm{C}_{0,25} \mathrm{~N}_{0,62}\right)$ & 11.3 \\
\hline
\end{tabular}

$* \mathrm{M}=\left(\mathrm{U}_{0.9} \mathrm{Pu}_{0,1}\right)$.

†Composition was calculated from point count, carbon and nitrogen content, and assumed X-ray density. 
The 0.5 -micron $\mathrm{UO}_{2}$ was employed during this reporting period (previous work used 3-micron $\mathrm{UO}_{2}$ ) to obtain more uniform blends and, hopefully, higher $\mathrm{M}(\mathrm{OCN})$ weight fractions. Several reaction mixes of $\mathrm{UH}_{\mathrm{X}}, \mathrm{UO}_{2}, \mathrm{PuO}_{2}, \mathrm{UN}$, and $\mathrm{UC}$ formulated to produce intended $\mathrm{M}\left(\mathrm{O}_{0.5} \mathrm{C}_{0.4} \mathrm{~N}_{0.1}\right)$ and $\mathrm{M}\left(\mathrm{O}_{0.5} \mathrm{C}_{0.2} \mathrm{~N}_{0.3}\right)$ were blended, compacted at $30,000 \mathrm{psi}$, heated to $1650^{\circ} \mathrm{C}$, and held for $5 \mathrm{hr}$ during synthesis.

The results of the experiments are summarized in Table 6, which also includes the previous synthesis results for comparison (Experiments 50 and 51).

Although good reproducibility was a chieved in the case of the intended $M\left(\mathrm{O}_{0.5} \mathrm{C}_{0.4} \mathrm{~N}_{0.1}\right)$ synthesis, the presence of the undesirable metal phase ruled out further work on this composition.

The products from the intended $\mathrm{M}\left(\mathrm{O}_{0.5} \mathrm{C}_{0.2} \mathrm{~N}_{0.3}\right)$ syntheses (Experiments 63 and 65 ) exhibited widely varying oxygen atom fractions ranging from 0.09 to 0.29 , as compared with 0.20 for the original run (Experiment 50). In addition, these materials were relatively porous. To increase their density, the synthesis products were crushed, repressed, and sintered. The Table 6 data show that sintering, as well as reheating the sintered product (Experiment 63B), not only densified these materials but also tended to increase the oxygen atom fraction of the monoxide-type phase. Although it appeared that additional development was required to obtain an equilibrium product stable at $1650^{\circ} \mathrm{C}$ in vacuum, this work was discontinued because the attainment of a single-phase M(OCN) composition with $\mathrm{O} / \mathrm{C}$ ratios of $5 / 2$ did not seem possible.

C. Intended $\mathrm{M}\left(\mathrm{O}_{0.3} \mathrm{C}_{\mathrm{y}} \mathrm{N}_{0.7-\mathrm{y}}\right)$ Compositions

Helium atmosphere syntheses of intended $\mathrm{M}\left(\mathrm{O}_{0.3} \mathrm{C}_{0.3} \mathrm{~N}_{0.4}\right)$ and $\mathrm{M}\left(\mathrm{O}_{0.3} \mathrm{C}_{0.4} \mathrm{~N}_{0.3}\right)$ by uranium metal reduction had yielded nearly single-phase $M(O C N)$ in previous work. ${ }^{4}$ The objective of these additional experiments was to determine the effect on composition of synthesizing in vacuum. Synthesis temperature variations from 1550 to $1750^{\circ} \mathrm{C}$ were investigated. Also, the effect on composition and density of 
TABLE 6 - SYNTHESIS AND SINTERING OF INTENDED $\left(\mathrm{U}_{0.9} \mathrm{Pu}_{0.1}\right)\left(\mathrm{O}_{0.5} \mathrm{C}_{\mathrm{y}} \mathrm{N}_{0.5-\mathrm{y}}\right)$ BY URANIUM METAL REDUCTION OF UO ${ }_{2}$ AND PuO 2 WITH UC AND UN IN VACUUM

\begin{tabular}{|c|c|c|c|c|c|c|c|c|}
\hline \multirow[b]{2}{*}{$\begin{array}{l}\text { Exp. } \\
\text { No. }\end{array}$} & \multirow[b]{2}{*}{$\begin{array}{c}\text { Intended } \\
\text { Composition* }\end{array}$} & \multirow{2}{*}{$\begin{array}{c}\text { Temp, }{ }^{\circ} \mathbf{C} \\
\text { (Total Hold } \\
\text { Time, hr) }\end{array}$} & \multicolumn{3}{|c|}{ Carbon Content, w/o } & \multicolumn{3}{|c|}{ Nitrogen Content, w/o } \\
\hline & & & $\begin{array}{c}\text { Total } \\
\text { Intended }\end{array}$ & $\begin{array}{c}\text { Total } \\
\text { Actual }\end{array}$ & $\begin{array}{l}\text { Contained } \\
\text { in } \mathrm{M}(\mathrm{OCN})\end{array}$ & $\begin{array}{c}\text { Total } \\
\text { Intended }\end{array}$ & $\begin{array}{c}\text { Total } \\
\text { Actual } \\
\end{array}$ & $\begin{array}{l}\text { Contained } \\
\text { in } \mathrm{M}(\mathrm{OCN})\end{array}$ \\
\hline $51 \ddagger$ & $M\left(O_{0.5} C_{0.4} \mathrm{~N}_{0.1}\right)$ & $1650(5)$ & 1.90 & 1.64 & 2.14 & 0.55 & 0.85 & 1.11 \\
\hline 66 & $\mathrm{M}\left(\mathrm{O}_{0_{5}} \mathrm{C}_{0,4} \mathrm{~N}_{0,1}\right)$ & $1650(5)$ & 1.90 & 1.67 & 2.12 & 0.55 & 0.64 & 0.81 \\
\hline $50 \ddagger$ & $\mathrm{M}\left(\mathrm{O}_{0,5} \mathrm{C}_{0,2} \mathrm{~N}_{0,3}\right)$ & $1650(5)$ & 0.95 & 1.01 & 1.27 & 1.66 & 2.32 & 2.93 \\
\hline 63 & $\mathrm{M}\left(\mathrm{O}_{0.5} \mathrm{C}_{0.2} \mathrm{~N}_{0.3}\right)$ & $1650(5)$ & 0.95 & 1.12 & 1.60 & 1.66 & 2.25 & 3.22 \\
\hline $63 \mathrm{~A}$ & $\mathrm{M}\left(\mathrm{O}_{0.5} \mathrm{C}_{0.2} \mathrm{~N}_{0.3}\right)$ & $1650(1)$ & 0.95 & 0.92 & 1.28 & 1.66 & 2.28 & 3.16 \\
\hline $63 \mathrm{~B}$ & $\mathrm{M}\left(\mathrm{O}_{0.5} \mathrm{C}_{0.2} \mathrm{~N}_{0.3}\right)$ & $1650(3)$ & 0.95 & 1.00 & 1.28 & 1.66 & 2.12 & 2.71 \\
\hline 65 & $\mathrm{M}\left(\mathrm{O}_{0.5} \mathrm{C}_{0.2} \mathrm{~N}_{0.3}\right)$ & $1650(5)$ & 0.95 & 1.02 & 1.39 & 1.66 & 1.74 & 2.37 \\
\hline $65 \mathrm{~A}$ & $\mathrm{M}\left(\mathrm{O}_{0,5} \mathrm{C}_{0,2} \mathrm{~N}_{0,3}\right)$ & $1650(3)$ & 0.95 & 0.99 & 1.41 & 1.66 & 1.75 & 2.49 \\
\hline
\end{tabular}

Metallographic Results,

Phases Present, and

Amount, w/o

Corrected

M(OCN) Density

$\mathrm{M}(\mathrm{OCN}) \quad \mathrm{MO}_{2-\mathrm{x}} \quad$ Metal

Composition $\dagger \quad \underline{\mathrm{g} / \mathrm{cm}^{3}}$

$\begin{array}{ccccc}77 & 18 & 5 & \mathrm{M}\left(\mathrm{O}_{0.36} \mathrm{C}_{0.45} \mathrm{~N}_{0.19}\right) & 13.0 \\ 79 & 21 & \text { Trace } & \mathrm{M}\left(\mathrm{O}_{0.41} \mathrm{C}_{0.44} \mathrm{~N}_{0.15}\right) & 12.3 \\ 79 & 21 & - & \mathrm{M}\left(\mathrm{O}_{0.20} \mathrm{C}_{0.27} \mathrm{~N}_{0.53}\right) & - \\ 70 & 30 & - & \mathrm{M}\left(\mathrm{O}_{0.09} \mathrm{C}_{0.33} \mathrm{~N}_{0.58}\right) & - \\ 72 & 28 & - & \mathrm{M}\left(\mathrm{O}_{0.16} \mathrm{C}_{0.27} \mathrm{~N}_{0.57}\right) & 12.7 \\ & & & & \\ 78 & 22 & - & \mathrm{M}\left(\mathrm{O}_{0.24} \mathrm{C}_{0.27} \mathrm{~N}_{0.49}\right) & 13.0 \\ 74 & 26 & - & \mathrm{M}\left(\mathrm{O}_{0.29} \mathrm{C}_{0.29} \mathrm{~N}_{0.42}\right) & 10.8 \\ 70 & 30 & - & \mathrm{M}\left(\mathrm{O}_{0.26} \mathrm{C}_{0.30} \mathrm{~N}_{0.44}\right) & 12.2\end{array}$
$\underline{\text { Remarks }}$
Sintering crushed product of
Exp. No. 63
Reheating product of Exp. No. $63 \mathrm{~A}$
Sintering crushed product of Exp. No. 65

$\mathrm{M}=\left(\mathrm{U}_{0.9} \mathbf{P} \mathbf{u}_{0.1}\right)$.

$\dagger$ Previous results from Reference 4 using 3 -micron $\mathrm{UO}_{2}$ starting material.

SComposition was calculated from point count, carbon and nitrogen content, and assumed X-ray density. 
sintering the crushed and repressed synthesis products at $1650^{\circ} \mathrm{C}$ was examined. The results for intended $\mathrm{M}\left(\mathrm{O}_{0.3} \mathrm{C}_{0.3} \mathrm{~N}_{0.4}\right)$ and $\mathrm{M}\left(\mathrm{O}_{0.3} \mathrm{C}_{0.4} \mathrm{~N}_{0.3}\right)$ are presented in Tables 7 and 8 , respectively.

With both compositions, synthesis at $1750^{\circ} \mathrm{C}$ was accompanied by a relatively large weight loss which was attributed to volatilization of uranium metal. At $1550^{\circ} \mathrm{C}$, weight losses were small and the weight fractions and the oxygen atom fractions of the monoxide phases were at least as high as obtained from higher temperature syntheses. The synthesis product densities, however, were relatively low. Invariably, a density improvement was achieved by sintering the crushed synthesis products. An example is illustrated in Fig. 3. Such dense structures are preferred for water corrosion tests.

\subsection{3 - Intended (UPu)(OCN) by Carbon Reduction in Vacuum}

The initial synthesis survey by carbon reduction in vacuum involved intended oxygen atom fractions of 0.5 to 0.8 and produced $M(O C N)$ weight fractions as high as $78 \mathrm{w} / \mathrm{o}{ }^{4}$ During this reporting period, higher weight fractions were sought by synthesis of the following intended compositions using this method: $M\left(O_{0.4} C_{0.3} N_{0.3}\right)$, $\mathrm{M}\left(\mathrm{O}_{0.3} \mathrm{C}_{0.4} \mathrm{~N}_{0.3}\right)$, and $\mathrm{M}\left(\mathrm{O}_{0.3} \mathrm{C}_{0.3} \mathrm{~N}_{0.4}\right)$. The starting materials $\left(\mathrm{C}, \mathrm{PuO}_{2}, \mathrm{UO}_{2}\right.$, and UN) were blended, compacted, heated to $1650^{\circ} \mathrm{C}$ and held for $5 \mathrm{hr}$.

The results of product characterization are shown in Table 9. The data show that $\mathrm{M}(\mathrm{OCN})$-phase weight fractions ranging from 88 to $97 \mathrm{w} / \mathrm{o}$ were obtained. Although the product of the intended $\mathrm{M}\left(\mathrm{O}_{0.3} \mathrm{C}_{\mathbf{0 . 4}} \mathrm{N}_{0.3}\right)$ synthesis yielded the highest weight fraction, its density was the lowest of the three materials. Water corrosion testing of all these materials is planned for the next reporting period. 
TABLE 7 - SYNTHESIS AND SINTERING OF INTENDED $\left(\mathrm{U}_{0.9} \mathrm{Pu}_{0.1}\right)\left(\mathrm{O}_{0.3} \mathrm{C}_{0.3} \mathrm{~N}_{0.4}\right)$ BY URANIUM METALREDUCTION OF UO AND PuO $_{2}$ WITH UC AND UN IN VACUUM

\begin{tabular}{|c|c|c|c|c|}
\hline \multirow[b]{2}{*}{$\begin{array}{l}\text { Exp. } \\
\text { No. }\end{array}$} & \multirow{2}{*}{$\begin{array}{c}\text { Temp, }{ }^{\circ} \mathrm{C} \\
\text { (Total Hold } \\
\text { Time, hr) } \\
\end{array}$} & \multicolumn{3}{|c|}{ Carbon Content, w/o } \\
\hline & & $\begin{array}{c}\text { Total } \\
\text { Intended }\end{array}$ & $\begin{array}{l}\text { Total } \\
\text { Actual }\end{array}$ & $\begin{array}{l}\text { Contained } \\
\text { in } \mathrm{M}(\mathrm{OCN}) *\end{array}$ \\
\hline 73 & $1750(5)$ & 1.43 & 1.38 & 1.46 \\
\hline 71 & $1650(5)$ & 1.43 & 1.46 & 1.63 \\
\hline 69 & $1650(5)$ & 1.43 & 1.34 & 1.53 \\
\hline 75 & $1620(5)$ & 1.43 & 1.46 & 1.80 \\
\hline 77 & $1550(5)$ & 1.43 & 1.50 & 1.56 \\
\hline $77 \mathrm{~A}$ & $1650(3)$ & 1.43 & 1.43 & 1.53 \\
\hline
\end{tabular}

\begin{tabular}{|c|c|c|}
\hline \multicolumn{3}{|c|}{ Nitrogen Content, w/o } \\
\hline $\begin{array}{c}\text { Total } \\
\text { Intended }\end{array}$ & $\begin{array}{l}\text { Total } \\
\text { Actual }\end{array}$ & $\begin{array}{l}\text { Contained } \\
\text { in } \mathrm{M}(\mathrm{OCN})\end{array}$ \\
\hline 2.22 & 2.77 & 2.94 \\
\hline 2.22 & 2.63 & 2.94 \\
\hline 2.22 & 2.06 & 2.35 \\
\hline 2.22 & 2.51 & 3.10 \\
\hline 2.22 & 2.34 & 2.44 \\
\hline 2.22 & 1.70 & 1.82 \\
\hline
\end{tabular}

Metallographic Results,

Phases Present, and

Amount, w/o

Corrected
M(OCN)

$\mathrm{M}(\mathrm{OCN}) \quad \mathrm{MO}_{2-\mathrm{x}} \quad$ Metal

Composition

Density,

${ }_{94}-$

$\mathrm{M}\left(\mathrm{O}_{0.17} \mathrm{C}_{0.30} \mathrm{~N}_{0.53}\right) \quad 12.0$

$\begin{array}{ll}\mathrm{M}\left(\mathrm{O}_{0.17} \mathrm{C}_{0.30} \mathrm{~N}_{0.53}\right) & 12.0 \\ \mathrm{M}\left(\mathrm{O}_{0.13} \mathrm{C}_{0.34} \mathrm{~N}_{0.53}\right) & 10.4\end{array}$

$\begin{array}{ll}\mathrm{M}\left(\mathrm{O}_{0.27} \mathrm{C}_{0.31} \mathrm{~N}_{0.42}\right) & 13.2\end{array}$

$\mathrm{M}\left(\mathrm{O}_{0.06} \mathrm{C}_{0.38} \mathrm{~N}_{0.56}\right) \quad 11.5$

$\mathrm{M}\left(\mathrm{O}_{0.24} \mathrm{C}_{0.32} \mathrm{~N}_{0.44}\right) \quad 11.5$

$\mathrm{M}\left(\mathrm{O}_{0.36} \mathrm{C}_{0.32} \mathrm{~N}_{0.32}\right) \quad 11.3$

Remarks

$8 \%$ weight loss

$2 \%$ weight loss

$1.5 \%$ weight loss

$1.1 \%$ weight los

Sintering of Exp. No. 77 product

${ }^{*} \mathrm{M}=\left(\mathrm{U}_{0.9} \mathbf{P u}_{0.1}\right)$.

†Composition was calculated from point count, carbon and nitrogen content, and assumed X-ray density. 


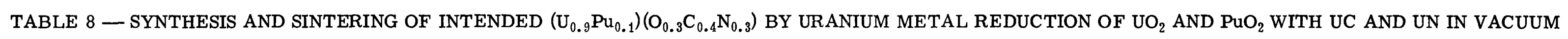

\begin{tabular}{|c|c|c|c|c|c|c|c|c|c|c|c|c|c|}
\hline \multirow{3}{*}{$\begin{array}{l}\text { Exp. } \\
\text { No. }\end{array}$} & \multirow{3}{*}{$\begin{array}{c}\text { Temp, }{ }^{\circ} \mathrm{C} \\
\text { (Total Hold } \\
\text { Time, hr) }\end{array}$} & \multicolumn{3}{|c|}{ Carbon Content, w/o } & \multicolumn{3}{|c|}{ Nitrogen Content, w/o } & \multirow{2}{*}{\multicolumn{3}{|c|}{$\begin{array}{c}\text { Metallographic Results, } \\
\text { Phases Present, and } \\
\text { Amount, w/o } \\
\end{array}$}} & \multirow{3}{*}{$\begin{array}{c}\text { Corrected } \\
\text { M(OCN) } \\
\text { Composition } \dagger \\
\end{array}$} & \multirow{3}{*}{$\begin{array}{c}\text { Density, } \\
\mathrm{g} / \mathrm{cm}^{3}\end{array}$} & \multirow[b]{3}{*}{ Remarks } \\
\hline & & Total & Total & Contained & Total & Total & Contained & & & & & & \\
\hline & & Intended & Actual & in $\mathrm{M}(\mathrm{OCN}) *$ & Intended & Actual & in $\mathrm{M}(\mathrm{OCN})$ & $\mathrm{M}(\mathrm{OCN})$ & $\underline{\mathrm{MO}_{2-\mathrm{x}}}$ & Metal & & & \\
\hline 74 & $1750(5)$ & 1.90 & 1.22 & 1.28 & 1.67 & 2.28 & 2.39 & 96 & 1 & 3 & $\mathrm{M}\left(\mathrm{O}_{0.31} \mathrm{C}_{0.27} \mathrm{~N}_{0.42}\right)$ & 12.5 & $33 \%$ weight loss \\
\hline 72 & $1650(5)$ & 1.90 & 1.98 & 2.13 & 1.67 & 1.73 & 1.89 & 93 & 7 & - & $\mathrm{M}\left(\mathrm{O}_{0.22} \mathrm{C}_{0.45} \mathrm{~N}_{0,33}\right)$ & 10.9 & $3 \%$ weight loss \\
\hline $72 \mathrm{~A}$ & $1650(3)$ & 1.90 & 1.78 & 1.93 & 1.67 & 1.84 & 2.00 & 92 & 8 & - & $\mathrm{M}\left(\mathrm{O}_{0.23} \mathrm{C}_{0.41} \mathrm{~N}_{0.36}\right)$ & 13.0 & Sintering of Exp. No. 72 product \\
\hline 70 & $1650(5)$ & 1.90 & 2.00 & 2.19 & 1.67 & 1.73 & 1.89 & 91 & 9 & - & $\mathrm{M}\left(\mathrm{O}_{0.21} \mathrm{C}_{0.45} \mathrm{~N}_{0.34}\right)$ & 13.2 & \\
\hline 76 & $1620(5)$ & 1.90 & 1.93 & 2.44 & 1.67 & 1.74 & 2.20 & 79 & 21 & - & $\mathrm{M}\left(\mathrm{O}_{0.08} \mathrm{C}_{0.52} \mathrm{~N}_{0.40}\right)$ & 11.4 & $2 \%$ weight loss \\
\hline $76 \mathrm{~A}$ & $1650(3)$ & 1.90 & 1.94 & 2.04 & 1.67 & 1.78 & 1.87 & 95 & 5 & - & $\mathrm{M}\left(\mathrm{O}_{0.24} \mathrm{C}_{0.43} \mathrm{~N}_{0.33}\right)$ & 12.5 & Sinter ing of Exp. No. 76 product \\
\hline 78 & $1550(5)$ & 1.90 & 1.94 & 2.09 & 1.67 & 1.75 & 1.89 & 93 & 7 & - & $\mathrm{M}\left(\mathrm{O}_{0.23} \mathrm{C}_{043} \mathrm{~N}_{034}\right)$ & 11.3 & $1.4 \%$ weight loss \\
\hline $78 \mathrm{~A}$ & $1650(3)$ & 1.90 & 1.82 & 1.94 & 1.67 & 1.65 & 1.76 & 94 & 5 & 1 & $\mathrm{M}\left(\mathrm{O}_{0.28} \mathrm{C}_{0.41} \mathrm{~N}_{0.31}\right)$ & 11.7 & Sintering of Exp. No. 78 product. \\
\hline 79 & $1550(5)$ & 1.90 & 1.93 & 2.00 & 1.67 & 1.70 & 1.76 & 96 & 4 & - & $\mathrm{M}\left(\mathrm{O}_{0.27} \mathrm{C}_{0.42} \mathrm{~N}_{0.31}\right)$ & - & 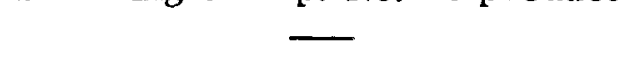 \\
\hline $79 \mathrm{~A}$ & $1650(3)$ & 1.90 & 1.85 & 1.98 & 1.67 & 1.69 & 1.82 & 93 & 7 & - & $\mathrm{M}\left(\mathrm{O}_{0.20} \mathrm{C}_{0.42} \mathrm{~N}_{0.38}\right)$ & $11.4 \ddagger$ & Sintering of Exp. No. 79 product \\
\hline
\end{tabular}

$* \mathrm{M}=\left(\mathrm{U}_{0.9} \mathrm{Pu}_{0.1}\right)$.

†Composition calculated from point count, carbon and nitrogen content, and assumed X-ray density.

$\ddagger$ Density determined on surface ground pellet; all other densities reported on as-fired pellets. 

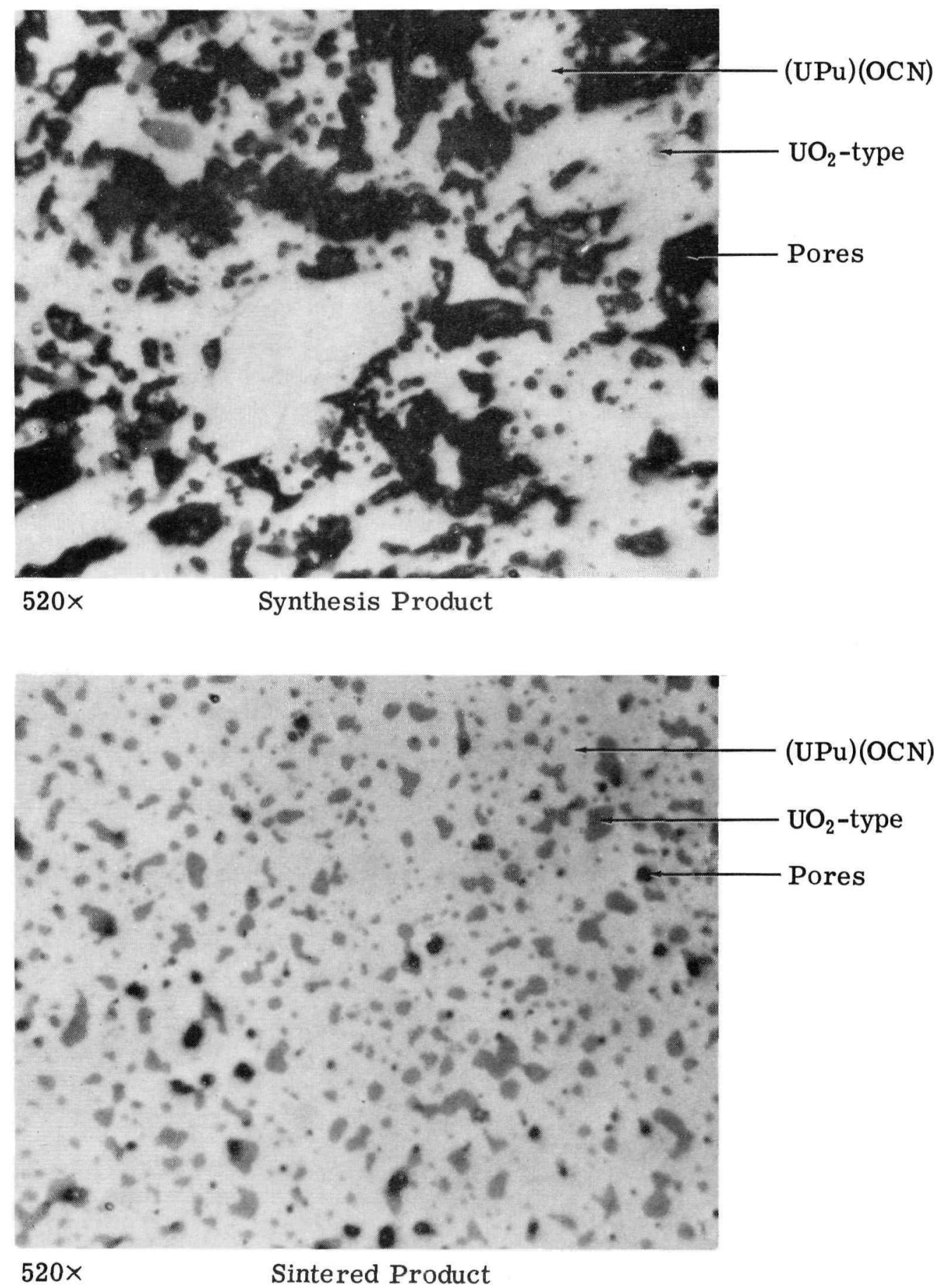

Fig. 3 - Density Improvement on Sintering Intended $\left(\mathrm{U}_{0.9} \mathrm{Pu}_{0.1}\right)\left(\mathrm{O}_{0.3} \mathrm{C}_{0.4} \mathrm{~N}_{0.3}\right)$ Synthesis Product

(Table 6, Exp. Nos. 72 and 72A) 
TABLE 9 - SYNTHESIS OF (UPU)(OCN) BY CARBON REDUCTION OF UO AND PuO $_{2}$ WITH UN IN VACUUM AT $1650^{\circ} \mathrm{C}$ FOR 5 HR

\begin{tabular}{|c|c|c|c|c|c|c|c|c|c|c|c|c|}
\hline \multirow{3}{*}{$\begin{array}{l}\text { Exp. } \\
\text { No. }\end{array}$} & \multirow{3}{*}{$\begin{array}{c}\text { Intended } \\
\text { Compositions* } \\
\end{array}$} & \multicolumn{3}{|c|}{ Carbon Content, w/o } & \multicolumn{3}{|c|}{ Nitrogen Content, w/o } & \multirow{2}{*}{\multicolumn{3}{|c|}{$\begin{array}{c}\text { Metallographic Results, } \\
\text { Phases Present, and } \\
\text { Amount, w/o } \\
\end{array}$}} & \multirow{3}{*}{$\begin{array}{c}\text { Corrected } \\
\text { M(OCN) } \\
\text { Composition } \dagger \\
\end{array}$} & \multirow{3}{*}{$\begin{array}{l}\text { Density, } \\
\mathrm{g} / \mathrm{cm}^{3} \\
\end{array}$} \\
\hline & & Total & Total & Contained & Total & Total & Contained & & & & & \\
\hline & & Intended & Actual & in $\mathrm{M}(\mathrm{OCN})$ & Intended & Actual & in $\mathrm{M}(\mathrm{OCN})$ & $\mathrm{M}(\mathrm{OCN})$ & $\mathrm{MO}_{2-\mathrm{x}}$ & Metal & & \\
\hline 80 & $M\left(O_{0.4} C_{0,3} N_{0.3}\right)$ & 1.43 & 1.88 & 2.13 & 1.66 & 1.49 & 1.69 & 88 & 12 & - & $\mathrm{M}\left(\mathrm{O}_{0,25} \mathrm{C}_{0,45} \mathrm{~N}_{0,30}\right)$ & 10.6 \\
\hline 81 & $M\left(O_{0,3} C_{0,3} N_{0.4}\right)$ & 1.43 & 1.81 & 1.97 & 2.22 & 1.88 & 2.04 & 92 & 8 & - & $\mathrm{M}\left(\mathrm{O}_{0.22} \mathrm{C}_{0.41} \mathrm{~N}_{0.37}\right)$ & 11.2 \\
\hline 82 & $M\left(\mathrm{O}_{0,3} \mathrm{C}_{0,4} \mathrm{~N}_{0,3}\right)$ & 1.90 & 2.17 & 2.24 & 1.67 & 1.47 & 1.52 & 97 & 3 & - & $\mathrm{M}\left(\mathrm{O}_{0.26} \mathrm{C}_{0.48} \mathrm{~N}_{0.26}\right)$ & 9.7 \\
\hline
\end{tabular}

${ }^{*} \mathrm{M}=\left(\mathrm{U}_{0.9} \mathrm{Pu}_{0.1}\right)$.

†Composition was calculated from point count, carbon and nitrogen content, and assumed X-ray density. 


\section{FUEL EVALUATION}

\subsection{INTRODUCTION}

Promising materials consisting of essentially single-phase compositions of $\mathrm{M}(\mathrm{OCN})$ were screened by corrosion testing in boiling water. Specimens of materials which survived the test were exposed to $550^{\circ} \mathrm{F}$ water in an autoclave. (UPu) $\mathrm{O}_{2}$ pellets will be tested under similar conditions for comparison.

Thermal diffusivity measurements are planned for those compositions exhibiting superior water corrosion resistance.

\subsection{WATER CORROSION}

\subsubsection{Boiling Water Tests}

Corrosion testing of specimens containing $91 \mathrm{w} / \mathrm{o} \mathrm{M}\left(\mathrm{O}_{0.21} \mathrm{C}_{0.37} \mathrm{~N}_{0.42}\right)$ was continued during this reporting period. A boiling water test was conducted on two pellets to check the reproducibility of the good corrosion resistance observed in the previous 73.5-hr test of this material. The pellets were immersed in separate flasks of boiling distilled water located in a nitrogen atmosphere glove box. The weight and dimensional changes found after $137 \mathrm{hr}$ are small, and they are presented in Table 10. Photographs of a pellet before and after the test are shown in Fig. 4. As in the previous test, the pellets changed color from grey to black and a small amount of material spalled off each pellet. This residue was recovered and in 
TABLE 10 - CORROSION DATA ON $\left(\mathrm{U}_{0.9} \mathrm{Pu}_{0.1}\right)\left(\mathrm{O}_{0.21} \mathrm{C}_{0.37} \mathrm{~N}_{0.42}\right)$ AFTER $137 \mathrm{HR}$ IN BOILING WATER

Pellet Number

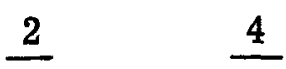

Weight Change

Grams

Per cent of original weight

$-0.0028-0.0030$

$-0.26 \quad-0.28$

Diameter Change

Inches

$+0.0004 \quad-0.0001$

Per cent of original diameter

$+0.21 \quad-0.05$

Height Change

Inches

$+0.0001 \quad-0.0001$

Per cent of original height

$+0.05-0.05$ 


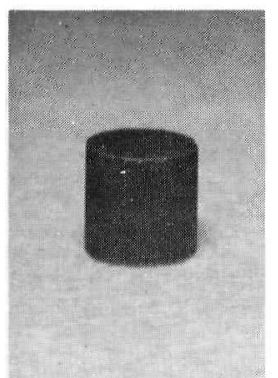

a. Before exposure

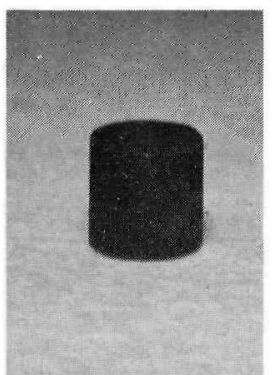

b. After exposure

Fig. 4 - Appearance of Specimen Containing $91 \mathrm{w} / \mathrm{o}$ $\left(\mathrm{U}_{0.9} \mathrm{Pu}_{0.1}\right)\left(\mathrm{O}_{0.21} \mathrm{C}_{0.37} \mathrm{~N}_{0.42}\right)$ before and after $137-\mathrm{hr}$ Test in Boiling Water 
each case it weighed $4 \mathrm{mg}$. These data are in substantial agreement with those obtained from the earlier test.

A boiling water test was also initiated on the $M\left(\mathrm{O}_{0.10} \mathrm{C}_{0.28} \mathrm{~N}_{0.62}\right)$ composition which was prepared during this quarter by uranium metal reduction in helium. After a 24-hr exposure, a negligible weight change was observed. Further testing of this material in boiling water is planned.

\subsubsection{Autoclave Tests}

In preparation for testing in high temperature water, the autoclave furnace and piping, shown in Fig. 5, were installed in a nitrogen atmosphere glove box. Two autoclaves (Kuentzel bombs), each of approximately 100-ml capacity, are heated simultaneously by the furnace. Prior to installation a testing procedure was established to assure that a satisfactory test in deoxygenated water would be conducted in the glove box. Preliminary experiments indicated that an oxygen level of $0.2 \mathrm{ppm}$ or less is achieved by bleeding off steam with the autoclave temperature maintained above $212^{\circ} \mathrm{F}$. The modified spectrophotometric Winkler method* was employed to determine the oxygen level in the water.

Autoclave corrosion tests in $550^{\circ} \mathrm{F}$ water were conducted on four' specimens containing $91 \mathrm{w} / \mathrm{o} \mathrm{M}\left(\mathrm{O}_{0.21} \mathrm{C}_{0.37} \mathrm{~N}_{0.42}\right)$. Initially, two specimens (one per autoclave) were tested in distilled deaerated water for $4 \mathrm{hr}$. Upon completion of the test, both specimens were found disintegrated. Two additional specimens were then exposed for $1 \mathrm{hr}$ to $550^{\circ} \mathrm{F}$ water with the same unfavorable results. The finely divided hydrolysis product from these tests was recovered and is being characterized by $\mathrm{X}$-ray diffraction analysis.

\subsection{THERMAL DIFFUSIVITY}

No thermal diffusivity measurements were performed during this quarter.

* Procedure published in ORNL Master Analytical Manual. 


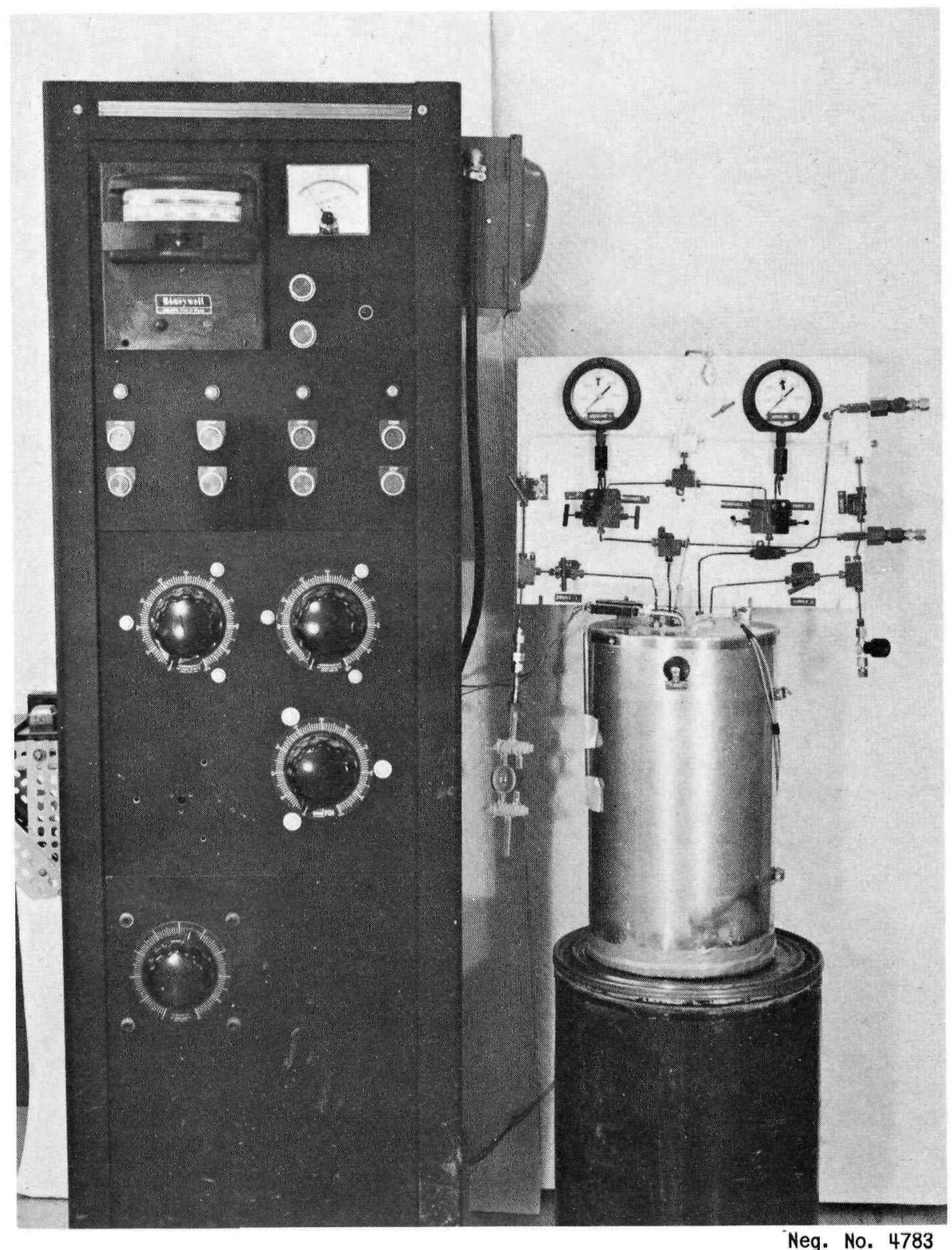

Fig. 5 - View of Autoclave Furnace, Piping, and Control Panel 


\section{CONCLUSIONS}

The major conclusions derived from the work this quarter are:

1. Although nearly single-phase (UPu)(OC) compositions can be obtained reproducibly from the synthesis of intended $\mathrm{M}\left(\mathrm{O}_{0.6} \mathrm{C}_{0.4}\right)$ by carbon reduction of the mixed dioxides in helium, the maximum oxygen atom fraction in the monoxide is no greater than the approximately 0.4 found in previously produced single-phase material.

2. Higher oxygen atom fractions (approaching 0.6 ) can be produced by the standard carbon reduction route; however, the weight fraction of the monoxide is limited to approximately $60 \mathrm{w} / \mathrm{o}$. The use of phenolformaldehyde resin in place of carbon powder as the reducing agent promises to increase the monoxide weight fraction.

3. The substitution of a submicron $\mathrm{UO}_{2}$ for the usual 3-micron starting material does not significantly affect the $M(O C)$-phase weight fraction or oxygen atom fraction resulting from carbon reduction syntheses.

4. The synthesis studies of various $(\mathrm{UPu})(\mathrm{OCN})$ materials employing the uranium metal and carbon reduction methods indicate that monoxidephase weight fractions of $90 \mathrm{w} / \mathrm{o}$ or greater are obtained when the intended oxygen atom fraction is restricted to a maximum of 0.3 and the intended oxygen to carbon atom ratio is no more than 1.

5. In the essentially single-phase $M(O C N)$ compositions produced, the sum of the oxygen and nitrogen atom fractions actually found is generally in 
good agreement with the intended composition.

6. Synthesis of $\mathrm{M}(\mathrm{OCN})$ compositions by uranium metal reduction in vacuum at $1750^{\circ} \mathrm{C}$ is accompanied by a high vaporization rate. Lower synthesis temperatures $\left(1550\right.$ to $\left.1650^{\circ} \mathrm{C}\right)$ produced essentially equivalent materials without significant weight loss.

7. Although a monoxide type material containing $91 \mathrm{w} / \mathrm{o} M\left(\mathrm{O}_{0.21} \mathrm{C}_{0.37} \mathrm{~N}_{0.42}\right)$ withstood exposure to boiling water for $137 \mathrm{hr}$, it disintegrated within $1 \mathrm{hr}$ in $550^{\circ} \mathrm{F}$ water. 


\section{WORK PLANNED FOR NEXT QUARTER}

During the next quarter, the fabrication of test specimens will be completed. Boiling water and autoclave corrosion tests will be performed on the most promising $M(O C)$ and $M(O C N)$ materials produced to date. Thermal diffusivity measurements will be made on selected compositions. Similar tests will also be performed on (UPu) $\mathrm{O}_{2}$ for comparison. 


\section{REFERENCES}

1. Stoops, R. and Hamme, J.: Phase Relations in the System Uranium-CarbonOxygen, J. Am. Ceram. Soc. (Feb. 1964).

2. Brett, W. et al.: The Substitutional Solubility of Oxygen in $U-C\left(U_{0.85} P u_{0.15}\right)-C$, and Pu-C, "Carbides in Nuclear Energy," Vol. 1, Macmillan Co. Ltd., London, 1964.

3. Magnier, P., Trouve, J., and Accary, A.: The Solubility of Oxygen and Nitrogen in Uranium Carbide, "Carbides in Nuclear Energy," Vol. 1, Macmillan Co. Ltd., London, 1964.

4. Study of Uranium-Plutonium Monoxides, Quarterly Progress Report, Period of April 1, 1965 through June 30, 1965, UNC-5132 (Sept. 15, 1965).

5. Study of Uranium-Plutonium Monoxides, Progress Report, Period of November 1, 1964 through March 31, 1965, UNC-5117 (Apr. 15, 1965). 
DISTRIBUTION

No. of

Copies

U. S. Atomic Energy Commission

Brussels Office

APO New York 09667

Attn: Senior AEC Representative . . . . . . . . . . .

U. S。 Atomic Energy Commission

New York Operations Office

Reactor Development Branch

Attn: Mr. J. Dissler .....................

Chief Patent Group

Brookhaven National Laboratories

Upton, L. I., New York

Attn: H. Potter ....... . . . . . . . . . . 。

U. S. Atomic Energy Commission

Foreign Activities, DRD

Washington 25, D。C.

Attn: Do Dalzell ......................

Assistant General Counsel of Patents

U. S. Atomic Energy Commission

Washington 25, D. C.

Attn: Roland Anderson ..................

U. S. Atomic Energy Commission

Technical Representative, DRD

Washington 25, D. C.

Attn: W. Rice . . . . . . . . . . . . . . . . . . 